\title{
Bidirectional Behavioral Selection in Mice: A Novel Pre-clinical Approach to Examining Compulsivity
}

\author{
Swarup Mitra ${ }^{1 *}$ and Abel Bult-Ito ${ }^{2,3 *}$ \\ ${ }^{1}$ Department of Pharmacology and Toxicology, State University of New York at Buffalo, Buffalo, NY, United States, \\ ${ }^{2}$ Department of Biology and Wildlife, University of Alaska Fairbanks, Fairbanks, AK, United States, ${ }^{3}$ OCRD Biomed LLC, \\ Fairbanks, AK, United States
}

\section{OPEN ACCESS}

Edited by:

Kurt Leroy Hoffman, Autonomous University of

Tlaxcala, Mexico

Reviewed by:

Pablo R. Moya,

Universidad de Valparaiso, Chile Jan Svoboda,

Academy of Sciences of the Czech Republic (ASCR), Czechia

Christopher Pittenger, Yale University, United States

*Correspondence: Swarup Mitra swarupmi@buffalo.edu Abel Bult-Ito

abultito@alaska.edu

Specialty section:

This article was submitted to Molecular Psychiatry,

a section of the journal

Frontiers in Psychiatry

Received: 28 May 2021

Accepted: 16 August 2021

Published: 08 September 2021

Citation:

Mitra S and Bult-Ito A (2021) Bidirectional Behavioral Selection in Mice: A Novel Pre-clinical Approach to Examining Compulsivity.

Front. Psychiatry 12:716619. doi: 10.3389/fpsyt.2021.716619
Obsessive-compulsive disorder (OCD) and related disorders (OCRD) is one of the most prevalent neuropsychiatric disorders with no definitive etiology. The pathophysiological attributes of OCD are driven by a multitude of factors that involve polygenic mechanisms, gender, neurochemistry, physiological status, environmental exposures and complex interactions among these factors. Such complex intertwining of contributing factors imparts clinical heterogeneity to the disorder making it challenging for therapeutic intervention. Mouse strains selected for excessive levels of nest- building behavior exhibit a spontaneous, stable and predictable compulsive-like behavioral phenotype. These compulsive-like mice exhibit heterogeneity in expression of compulsive-like and other adjunct behaviors that might serve as a valuable animal equivalent for examining the interactions of genetics, sex and environmental factors in influencing the pathophysiology of OCD. The current review summarizes the existing findings on the compulsive-like mice that bolster their face, construct and predictive validity for studying various dimensions of compulsive and associated behaviors often reported in clinical OCD and OCRD.

Keywords: OCD, artificial selection, spontaneous compulsive-like phenotype, behavioral heterogeneity, facepredictive-construct validity, desformylflustrabromine, OCRD

\section{INTRODUCTION}

The prevalence of obsessive-compulsive disorder (OCD) ranges from 1 to $3 \%(1,2)$ including a lifetime prevalence of $1.6 \%$ (3) to $2.3 \%$ (4) and a 12 -month prevalence of $1.2 \%$ in the United States (US) (4), and a point prevalence of 3.3\% in India (5) and 1.7\% in Greece (6). It was first described as a psychiatric condition about 100 years ago $(7,8)$. The World Health Organization has indicated OCD to be the leading global cause of morbidity (9) that has however declined in the recent times due to refinements in the understanding of the prevalence of the condition. Previously OCD has been considered among the top 20 causes of years of life spent with disability for patients between 15 and 44 years of age (10). In 1990, costs related to OCD in the US were estimated to be $\$ 8.4$ billion (11). Costs include medical care and lost productivity related to functional disabilities. OCD has a large impact on quality of life and functional disabilities including impairments in mental health, social and household functioning, work outcomes and physical health (12-19). The average time from OCD onset to initial treatment is over 7 years (20-22) adding to the patient's burden of decreased quality of life during a significant period of their lives. This is mainly because patients are inclined to conceal their symptoms fearing they will appear abnormal and seek medical attention only when other co-morbid conditions, such as anxiety and depression, exacerbate the disorder $(23,24)$. Ineffective identification of specific symptoms is also one of the reasons for delayed diagnosis (25). 
OCD patients suffer from persistent obsessive thoughts and compulsive repetitive behaviors to alleviate uncomfortable feelings of anxiety and distress (23, 26-30). Compulsions are typically meant to neutralize the obsessive feelings (31), but provide only transient relief leading to reinforcement of the behaviors and continuation of the obsession-compulsion cycle (29). Obsessions can be thematic, such as fear of contamination, pathological doubt, or need for symmetry/order. Compulsive behaviors involve washing, seeking, counting, sorting, checking and searching $(23,26-30)$. Some patients experience obsessionsonly symptoms without any compulsive ritualistic behaviors. An example is that of fear of causing harm to others or self (29). Many studies use the Yale-Brown Obsessive-Compulsive Scale (Y-BOCS scale), an 10-item clinically administered scale (29), to clinically characterize and identify the occurrence and types of obsessive-compulsive symptoms (32). Further enhancements to this scale involve the Dimensional Yale-Brown ObsessiveCompulsive Scale (DY-BOCS) which categorizes OCD into 6 distinct dimensions (33). They are (i) aggression/checking, (ii) sexual/moral/religious, (iii) symmetry/ordering/counting, (iv) contamination/washing, (v) hoarding, and (vi) others (29, 33, 34). In addition, researchers have divided OCD into subgroups based on familiality, gender, age of onset and comorbid patterns (35-38). The specific OCD dimensions vary from study to study $(4,29,36,39-41)$, which shows no consensus in the field. This heterogeneity in OCD symptoms complicates identification of candidate genes (29) and the choice of initial pharmacotherapy, which may explain why $40-60 \%$ of OCD patients do not respond to initial selective serotonin reuptake inhibitor (SSRI) treatment $(42,43)$, requiring repeated treatments with different drugs until a response is observed (44).

The age of onset of OCD ranges from early in childhood to adulthood (29). Onset after 30 years of age is highly unusual $(4,44)$. Approximately $30-50 \%$ of the patients have onset of symptoms before 10 years of age indicating neurodevelopmental aspects to the disorder (45-47). Interestingly, in childhood onset OCD, males are more commonly affected than females with a ratio of $\sim 2: 1-3: 1$ (males: females). This ratio however shifts to 1:1.4 among patients with onset during or after puberty (48). Additionally, there is a significant overlap in symptom dimensions in patient subgroups between early and late onset cohorts. Though genetic linkage, candidate gene and genome wide association studies in humans (49-54) have indicated several genetic associations, the precise causative factors remain elusive (31). This could be attributed to the heterogeneous nature of the disorder which in turn is influenced by several factors such as sex differences, environmental exposures, genetic variations, neurotransmitter systems and physiological status.

The Diagnostic and Statistical Manual of Mental Disorders 5 (DSM-5) now classifies OCD within obsessive-compulsive and related disorders (OCRD) (55). OCRD include OCD $(23,26-30,56)$, excoriation disorder (excessive skin picking) (57-62), trichotillomania (excessive hair pulling) (57, 61, 6367), onychophagy (excessive nail biting) (57, 61, 68), body dysmorphic disorder (excessive/obsessive thinking about one or more perceived defects or flaws in one's appearance that are minor or not obvious to others) (69-76), and hoarding disorder (excessive collection of objects of limited use) (77-82). The most common comorbid disorders associated with OCD are depression and anxiety (83-86). Other less frequently observed comorbid symptoms include social phobia, Tourette's syndrome, bipolar disorder, attention deficit-hyperactivity disorder, dysthymic disorder, alcohol use disorder, eating disorders, and other OCRD (87-98). One of the challenges associated with such elaborate symptom and comorbidity features of OCD is finding a relevant animal model that enables examining the neural and behavioral underpinnings underlying the clinical aspects of the disorder.

OCD is most likely polygenic (29, 99, 100), although genes of major effect cannot be ruled out, especially for small groups of OCD patients and dimensions of OCD (101-103). Heritability estimates for OCD vary from 26 to $65 \%$, which may depend on symptom dimension $(29,39$, 104-106). Genes involved in serotonergic, dopaminergic and glutamatergic signaling pathways have been implicated with pathway-specific pharmacotherapy for OCD (107-125). Genetic linkage, candidate gene and genome-wide association studies have identified many gene candidates that may affect OCD or convey a susceptibility for development of $\operatorname{OCD}(29,126,127)$, including the glutamatergic system (99, 123, 127-136). Despite all these efforts, identifying putative genes that contribute to OCD reliably and consistently across studies has been difficult because OCD is a complex, heterogeneous and most likely polygenic trait $(29,99,100)$ with several genes having small effects that are difficult to reveal at the level of individual genes $(29,126)$. Thus, compulsive-like behaviors expressed in single gene manipulations may not be mimicking OCD, or may be relevant for only a small percentage of OCD patients $(137,138)$ or identify susceptibility genes for the expression of $\operatorname{OCD}(130,139)$.

While prior reviews have discussed extensively the existing animal models of OCD, we only describe these animal models briefly here and focus particularly on the spontaneous compulsive-like nest-building phenotype (140-145) and argue in favor of this model as suitable for understanding behavioral plasticity underlying expression of compulsivity typically reported in OCD and OCRD.

\section{SPONTANEOUS ANIMAL MODEL FOR OCD}

Spontaneous animal models use the concept of innately occurring stereotypic behaviors, motor behaviors, or adjunctive behaviors that are induced through behavioral manipulations (146-148). Animal behaviors that are suggested to be relevant to $\operatorname{OCD}(149,150)$ include excessive grooming $(151,152)$, acral lick (153-155) and stereotopies $(156,157)$ in several species such as dogs, psychogenic alopecia in cats (158-160), repetitive pacing in captive wild animals (161-163), feather picking in birds (151, 164-166), repetitive behaviors, such as running, flipping and jumping in deer mice $(167,168)$ and cribbing in horses $(169-$ 173), spontaneous alteration (174), compulsive checking by mice and rats (174), marble burying behavior (digging) in mice (140$145,175)$ and rats $(149)$, signal attenuation in rats $(176,177)$, and nest-building behavior (140-145). Most of these compulsive-like 
behaviors in these animals have limited utility because they are quite unpredictable, have to be induced, necessitating behavioral evaluation of an entire generation, or occur sporadically. As an exception, excessive forms of grooming, nest-building and digging behaviors have shown to be predictable and have face, predictive and construct validity for understanding compulsive behaviors associated with $\operatorname{OCD}(23,29,99,140-145,178-180)$. Nest-building and digging behaviors in mice bidirectionally selected for excessively high and low levels of nest-building behavior remain stable across generations $(181,182)$.

\section{INDUCED COMPULSIVE-LIKE BEHAVIORS}

Rats and mice can be induced to express compulsive-like behaviors by treatment with drugs such as dopamine (D2/D3) receptor agonist quinpirole (183-186), serotonin receptor (5HTR) agonists 5-methoxy-N,N-dimethyltryptamine (5-MeODMT; non-selective agonist), 8-hydroxy-2-(di-npropylamino)-tetralin hydrobromide (8-OH-DPAT; 5HT-1AR agonist) (187-189) and meta-Chlorophenylpiperazine (mCPP; 5HT2CR agonist) $(190,191)$. The drug-induced compulsive-like behaviors provide a wealth of information on the underlying neurobiology of the disorder. For example, mCPP exacerbates OCD symptoms in clinical populations $(192,193)$. 5HT1BR agonist-induced OCD-like mouse model (194-197) is another model that reveals how serotonin reuptake inhibitors (SRI) attenuate OCD-like behaviors by desensitizing orbitofrontal 5HT1BRs (195). One of the limitations of these models however could be in expanding on the understanding of the onset of action (198). Behaviorally induced compulsive-like behaviors include schedule-induced polydipsia (199) and food-restrictioninduced hyperactivity in rats, stress- and fear-induced marble burying in mice $(149,200)$ and water spray-induced grooming (201). These induced compulsive-like behaviors have varying degrees of validity $(149,200)$.

\section{GENETICALLY MODIFIED MICE THAT EXPRESS COMPULSIVE-LIKE BEHAVIORS}

Mutant, gene knockout, or gene knockdown mice have been shown to express compulsive-like behaviors that are relevant to OCD. These have resulted in several interesting animals systems, which have varying degrees of validity for studying OCD $(174,199,200,202-205)$. The Hoxb8-knockout mouse was the first transgenic pre-clinical model to study OCD. Hoxb8knockout leads to pathological grooming behavior which is triggered from aberrant Hoxb8 expression in implicated brain regions underlying OCD (206). The SAPAP3-knockout mice display excessive self-grooming starting at 4-6 months of age that leads to head skin lesions (178) and have dysfunction in cortico-striato-thalamo-cortico (CSTC) circuit (23, 29, 48, 99, 179, 180) components (207-211). SAPAP3 polymorphisms may be associated with early onset OCD (212) and grooming disorders (213) and SAPAP3 heterozygous variants are present in $4.2 \%$ of trichotillomania/OCD patients and in $1.1 \%$ of controls (137). Compulsive-like behavior in 5-HT2C knockout mice includes highly organized patterns of non-food chewing (137, $214)$, but they also have other abnormalities (214, 215). Slitrk5knockout mice display compulsive-like grooming and corticostriatal dysregulation (216) and rare mutations in this gene may be associated with OCD (138). Overexpression of the Slcla1/EAAT3 glutamate transporter increases anxiety-like and repetitive behaviors in mice along with cortico-striatal deficits that is decreased to normal with the treatment of fluoxetine or clomipramine (217). This gene affects components of the CSTC circuit $(130,205)$ and Slc1a1/EAAT3 single nucleotide polymorphism have been associated with susceptibility for OCD $(130,218)$. These genetic models provide critical insight on the neurobiological aspects underlying pathophysiology of OCD.

\section{FACE, PREDICTIVE, AND CONSTRUCT VALIDITY OF ANIMAL MODELS FOR OCD}

To mimic a human psychiatric condition, animal behaviors should have face, predictive and construct validity (219-221). Although OCD and other OCRD symptoms generally impair normal functioning (12-19), OCD-like behaviors in animals do not necessarily result in overt dysfunction, but are nevertheless very useful to mimic compulsivity common to OCD (219-221).

\section{Face Validity}

Face validity refers to the degree of phenomenological similarity between the animal and the disease it is expected to model (201, 221). Phenomenological identity comprises of behavioral and or cognitive dimensions that mimic the disease symptomology (221). Considering the species divergence, the "extent of similarity" patterns are typically considered as qualifying criteria for an animal model of a disorder. Obsessions cannot be modeled in animals due to the specificity of the social and environmental contexts in humans that drive dimensions of obsessive thoughts $(150,201)$. Behaviorally, only the compulsions are manifested and therefore can be observed in animal models. Hence when cataloging OCD, behavioral patterns in existing animal models refer to the expression of an otherwise normal phenotype in an excessive and repetitive manner (149, 199, 204). The persistent and exaggerated behavioral patterns can be linked to the clinical dimensions of compulsivity as commonly observed in patient populations. Stereotypic grooming is the most commonly observed dysregulated innate behavior in animal models of compulsivity (201). Other spontaneous compulsive behaviors include patterned jumping, circling, backflips and summersaulting as seen in the deer mice model (222). Since the current review focusses on the spontaneous mouse model (140145), we will restrict the review on the compulsive behaviors pertaining to the model that can serve as an useful tool to understand factors that modulate compulsivity in OCD and OCRD.

\section{Predictive Validity}

Predictive validity relies on the therapeutic evaluation of an animal model to assess if first line therapy in the model in question mimics clinical potency (221). Predictive validity is not aimed at ensuring replication of translational specificity 
with respect to human pathophysiology but rather emphasizes on the therapeutic responses (221). A comparable response to the first line treatment options corresponds to a humananimal correlation of therapeutic outcomes. Predictive validity pertaining to OCD can only be limited to pharmacological or neurosurgical interventions since behavioral therapies such as cognitive behavioral therapy cannot be evaluated in animals (201, 223). To this end most animal models fulfilling predictive validity for OCD are evaluated for chronic regimens of selective serotonin reuptake inhibitors (SSRI), a class of drugs that show remission in certain patient subgroups (224). Additionally, neurosurgical methods such as deep brain stimulation has also been assessed in the SAPAP3-knockdown model of OCD (211). The SSRI typically function by blocking the serotonin transporters (SERT) thereby prolonging the serotonin concentration at the synapses for rewiring the neural substrates underlying behavioral anomalies $(225,226)$.

\section{Construct Validity}

Construct validity refers to the comparable molecular and physiological mechanisms between the animal model and the disease it represents (221). Since the exact neural mechanisms of OCD are yet to be elucidated, construct validity of a model is reliant on correlative evidence from functional imaging studies on human patients (201). This typically involves substrates in the $\operatorname{CSTC}(23,29,48,99,179,180,227)$. Ovarian hormones, or the implicated neurotransmitter systems that can explain the behavioral correlates (face validity) and treatment response (predictive validity) are others (175). An alternative way to evaluate construct validity is to have animal models that recapitulate certain aspects of cognitive anomalies such as cognitive deficits, and reversal learning commonly observed in OCD patients $(228,229)$.

\section{BIDIRECTIONAL SELECTION FOR SPONTANEOUS COMPULSIVE-LIKE BEHAVIORS}

The spontaneous compulsive-like mouse model was developed through bidirectional selection for high and low levels of nestbuilding from an HS/ibg outbred mouse stock population (181, 182, 230). The HS/ibg strain was derived through crossing of eight house mouse (Mus musculus) inbred strains [A, AKR, BLB/c, C3H/2, C57BL, DBA/2, Is/Bi, RIII; (181, 231)]. Bidirectional selection resulted in three levels of nest-building behavior (with two replicate strains within each level). The replicates within each level of nest-building were maintained as separate strains, i.e., not interbred with the other replicate strains, but subjected to the same selection regime $(181,182)$. This resulted in two HA strains (HA1 and HA3) that consistently display high and excessive levels of nesting with a 40-fold difference in the amount of cotton used when compared to the two LA strains (LA1 and LA2) which display very low levels of nesting. The LA strains are therefore considered noncompulsive. The two randomly-bred strains (CA1 and CA3) serve as a selection control and show intermediate levels of nesting $(143,182)$.

\section{EXCESSIVE NEST-BUILDING AND MARBLE BURYING FULFILL THE VALIDITIES FOR COMPULSIVITY IN HUMANS}

As a naturalistic model, the spontaneously compulsive-like mouse strains exhibit two topographies of excessiveness and repetitiveness. They are compulsive-like nest builders (puling excessive amounts of cotton into their cage) and diggers (excessive burying of marbles) $(140,141,143)$.

\section{Nest Building}

For small rodents such as mice, nesting is a physiological adaptation that is critical for heat conservation, reproduction and to thwart predators (232-236). Healthy nesting is an essential indicator of welfare among animals and alteration in normal nesting patterns could be indicative of change in health or welfare (237). As nest-building is energetically costly, it can make rodents vulnerable to predation $(238,239)$. Hence it becomes imperative from an adaptation standpoint to create a dynamic balance between behavioral engagement and energy conservation (240). According to the security motivation theory of OCD, individuals engage in species-specific behaviors to handle potential danger and no consummatory stimuli should interfere with the impulse control of behavioral continuity $(241,242)$. Cotton acts as a consummatory stimuli for the compulsive-like strains that exhibit almost negligible latency to initiate nest-building when introduced to cotton for the first time showing rapid, forceful and repeated movement of the front paws and mouth for extended periods of time $(140,141,143)$. Since latency to nesting is considered as a good indicator for motivation (240) such excessive and repetitive patterns of nest-building fails to prioritize conserved behavioral patterns mimicking loss of impulse control which is often reported in human OCD patients (243-245). This perseverant action leads to pulling of excessive amount of cotton through the cage top metal bars over prolonged periods of time leading to uncontrolled hoarding of nesting material $(140,141,143)$. Both the sexes of the HA strains accumulate massive amounts of cotton in the cages that are incorporated into a functional nest and in most animals, the cotton fills the entire cage. This is in stark contrast to the normal nesting phenomenon in the control strains (CA strains) which appears to be focused on energy conservation and the building of a functional nest that typically have the minimal amount of nesting material required $(140,141,143)$. The small nest-builders (LA strains) do not collect sufficient amounts of cotton to build a functional nest $(181,182,234)$. Therefore, nest-building in the big nest-builders (HA strains) recapitulates several dimensions of compulsive behaviors with repetitiveness and excessiveness that shows face validity for understanding OCD.

With greater knowledge of the neurobiological underpinnings mediating nesting behavior it is evident that learning and memory play a significant role in expression of this phenotype. 
The hippocampus and prefrontal cortex are brain regions typically implicated in nest-building. Studies have indicated that lesions in the hippocampus or PFC disrupt nest formation (246-249). Further, disrupting GABAergic signaling in the neuropeptide $\mathrm{Y}$ interneurons of the PFC augments nest-building phenotype (250). Similarly, perturbing serotonin signaling results in poor nest construction (251). Nest-building also integrates intricate sequences of discrete motor learning that involves alterations in physical actions often in a stereotypic manner. Such perseverant action parallels reward based training paradigms indicating involvement of brain substrates underlying motor and motivational behaviors (252). Dopaminergic activation in reward circuitry is one of the molecular hallmarks of nesting behavior which integrates incentive and reinforcing phenotypes (252). Nest-building therefore encompasses sensorimotor, goaldirected and reward based neural mechanisms involving several neurotransmitter systems. Since, aberration of the abovementioned regions and neurotransmitter mechanisms has been documented in several studies investigating clinical populations (253-259), nest-building can be considered as a relevant and suitable behavioral phenotype to address some aspects of compulsivity in humans.

\section{Marble Burying}

Burying and digging are core behavioral attributes in rodents (260). These behavioral repertoires often involve stereotypic actions that align to more specific outcomes. For example, burying allows displacement of noxious or non-noxious objects while digging involves displacement of substrates (261). Marble burying behavior is one of the most widely studied models to assess compulsive-like phenotypes (140, 143, 262-265). The concept of marble burying utilizes the natural tendency of mice or rats to bury harmless or noxious objects in the bedding provided to them (174). Since studies (266-268) have shown that rodents typically do not tend to avoid the marbles, or get habituated after repeated exposures, marble burying is a good indicator of a compulsive-like but not an anxiety-like phenotype $(140,267,268)$. The compulsive theory of marble burying is based on the fact that non-reactivity of the marbles fails to provide stimuli for ending the investigation leading to frustrated burying of objects that gets stereotypic in nature (149). Marble burying can be mapped to the inability to realize task completion in OCD patients (241), thereby establishing its face validity. Similar to nest-building, marble burying requires hippocampal and cortical regions for functional outcomes (260, 269). Marble burying also integrates motor regions such as the striatal components for executing repetitive locomotor actions mediating the compulsive digging behavior $(267,268,270,271)$. Further, several neurotransmitter systems have been implicated in influencing the behavior (272-276). The compulsive-like HA strains demonstrate a persistent compulsive-like marble burying behavior (140, 143). Most mouse models tested for marble burying as an indicator of compulsive-like behavior typically bury on an average $10-12$ marbles $(222,277,278)$. It is interesting to note that such burying attributes often correlate to anxiety-like and not compulsive-like responses. On the contrary, compulsive burying in the HA strains comprise of aggravated and stereotypic digging of the marbles averaging 18-20 marbles (140-145, 279). Upon completion of digging, mice often appear agitated with rapid locomotor movements and perform frenzy investigation of the apparatus. Further, the HA strains engage in burying behavior throughout the entire duration of the test despite marbles being buried. The non-compulsive-like LA strains on the other hand bury 6-8 marbles on an average which is often accompanied by freezing behavior and lower locomotor activities, while the CA control strains bury 10-13 marbles with intermediate motoric activity $(140,141,143)$. The non-compulsive-like LA strains therefore conform to a more anxiety-like phenotype that can be characterized as risk aversion $(280,281)$, while the control strains lie intermediate on the spectrum.

This abnormal behavioral excessiveness exhibited through nest-building and marble burying in the spontaneous compulsive-like mouse strains qualifies these mice to be a suitable naturalistic model to investigate behavior and the nervous system by proxy. The presence of non-compulsive-like LA and control strains further strengthens the phenotypic rigor in terms of establishing a behavioral gradient across strains to better understand the behavioral anomaly expressed as a function of genetic selection and variation. Further, nest-building and marble burying behaviors are malleable to genetic $(181,182)$, pharmacological $(140,142,145,279)$ and environmental $(181,182)$ manipulations serving as important tools for dissecting neural substrates mediating functional outcomes. Nest-building behavior draws a parallel with hoarding in human patients as reported earlier, while marble burying can recapitulate failure of task completion that falls in the realm of compulsive checking as seen in many OCD patient subsets (241). Excessive nest-building and marble burying in the compulsivelike HA mouse strains can also form disparate compulsive-like traits (145) that can be utilized to better understand disparate compulsive traits in patient subgroups. Moreover, the degree of nest-building in the HA strains always exhibits consistent and positive correlation with marble burying providing a basis for comparison of behavioral traits through sex, treatment and physiological differences $(140-145,279)$.

\section{ADJUNCT BEHAVIORS IN THE SPONTANEOUS COMPULSIVE-LIKE MOUSE MODEL}

Apart from expressing variable compulsive-like behaviors, the nest-building mouse strains exhibit an array of other adjunct phenotypes that vary among the three nesting phenotypes and between replicates within each phenotypes which is also influenced by sex differences (143). Such variable expressions pertain to anxiety-, depression- and cognitive-like domains (143). Comorbidities are a critical component of the symptomatic repertoires in OCD patients. These comorbid symptoms vary within clinical subgroups and often make prognosis cumbersome (88). Most animal studies so far have focused on dissecting compulsive-like behaviors as a function of behavioral, genetic, pharmacological and circuit-based manipulations (see sections Spontaneous Animal Model for 
OCD, Induced Compulsive-Like Behaviors, and Genetically Modified Mice That Express Compulsive-Like Behaviors above). Characterization of associated phenotypes have been largely unexplored in various model organisms for OCD. We have exhaustively identified the domain specific behavioral expression profile of the nesting mouse strains. In general, the compulsivelike HA strains show less anxiety on anxiety-like assessments in open field and elevated plus and zero mazes (140, 141, 143). Interestingly, anxiety-like responses in the compulsive-like mice vary based on sex, strain differences and on the difficulty level of the tests allowing to identify distinct behavioral patterns across variable emotional dimension of affective behaviors. For example, the male HA strains exhibit strain differences when (141) evaluated on elevated plus maze but show no such replicate strain variation when tested for the open field (143). Moreover, HA2 females and HA1 males show a negative correlation between specific compulsive-like traits and anxietylike responses. Nest-building in the HA2 females and marble burying in the HA1 males correlate with increased anxiety in the elevated plus maze indicating a complex genetic architecture driving functional outcomes that parallel clinical heterogeneity (143). The non-compulsive-like LA strains on the other hand exhibit anxiogenic responses in the anxiety-like evaluations of open field and elevated mazes (140, 143). For cognitive-like tests as determined through novel-object recognition, one of the CA female strains has higher object recognition memory when compared to the respective males. No differences are observed for the HA and the LA strains. For depression-like forced swim behavior, the strains display a significant sex and sex by strain interaction effects (143). At the biochemical level, the compulsive-like HA strains and the non-compulsive-like LA strains mount higher corticosterone levels than the selection controls (143). These variations could be attributed to genetic drift or founder effects $(181,182)$. Such complex behavioral expression could be essential in understanding the symptomatic framework and underlying neural substrates of OCD subgroups. Several heritability studies have pinpointed toward a lack of single identifier gene and often report an interaction of multiple gene networks that overlaps with environmental factors resulting in discrete expression of primary symptoms and associated comorbidities (29). Thus, it becomes imperative to examine an animal model that displays both primary and secondary behavioral attributes that is structured upon genetic variations due to bidirectional selection.

\section{STRAIN AND SEX DIFFERENCES IN SPONTANEOUS MOUSE MODEL: RECAPITULATING CLINICAL HETEROGENEITY}

OCD most likely has a polygenic basis. Family studies, segregation analysis studies, candidate gene studies and genome wide association studies have consistently reported and established heritability and genetic mechanisms as important causative factors of OCD. Family studies have indicated that early onset OCD has a familial basis $(282,283)$. Family studies with adult probands have revealed that OCD is familial with increased risk of occurrence among relatives of patients with childhood onset OCD (284-286). Around 100 candidate gene studies have focused on the genetic variants predominantly within neurotransmitter pathways (127). One of these candidate gene studies has shown that OCD might be associated with polymorphisms in serotonin system related genes such as 5HTTLPR (serotonin-transporter linked polymorphic region) and HTR2A (5-hydroxytryptophan receptor 2A) (287). The same study also pinpointed genetic variations in monoamine oxidase and catechol-o methyl transferase genes only in male patients and dopamine system related genes such as DAT-1 (Dopamine active transporter 1 gene) and DRD3 (Dopamine receptor D3) (287). In addition, other genome wide association studies have identified various genes that code for essential neurobiological substrates (53, 288-290), which are critical for neuronal transmission and plasticity, such as DLGAP1 (guanylate kinase-associated protein) and BTBD3 (BTB domain containing protein 3). Despite such exhaustive attempts, these GWAS studies have yielded unreliable results with no specific hits and minimal replication of the aforementioned genes that can be conclusively tied to the pathophysiology of the disorder. Interestingly, a recent study identified large-effect size causes pertaining to de novo coding variants as risk factors for OCD (291).

Earlier onset of OCD in males when compared to females (292), bimodal distribution of onset in females and exacerbation of symptoms during various reproductive phases (293) point toward the role of steroid hormones in OCD. Sex hormones are mainly steroids that are produced by the gonads (294). The most relevant are female sex hormones estrogen and progesterone, and the male sex hormone testosterone. These hormones regulate and influence global sexual functions like pregnancy, pubertal changes and sexual behavior (295). Estrogen and progesterone have neuromodulatory effects in the central nervous system either through intracellular action or via neurotransmitter systems (296-298). These sex steroids further metabolize into neurosteroids, which have anti-convulsive (299), anti-depressant (300) and anti-anxiety (301) properties through modulation of GABA and glutamate receptors (302). The emphasis of sex steroids in influencing onset and exacerbation of OCD symptoms are more relevant to female OCD patients. This is mainly because women are at risk of developing the disorder during various reproductive phases (303).

Nesting can be attributed to polygenic mechanisms and often exhibit a complex genetic architecture (181, 182). There are several genomic regions that are associated with the behavior and often exert dominance and additive effects (181, 304306). Realized heritability for nest-building is 0.30 (181, 182). This is in the same range as heritability estimates for OCD that range from 26 to $65 \%$, which may depend on symptom dimension $(29,39,104-106)$. Replicate diffferences within the same nesting phenotype, i.e., HA, control, and LA strains, for other behaviors and traits are most likely due to founder effects and/or genetic drift $(181,182)$. Therefore, comparing nest-building phenotype and other behaviors and traits across replicate strains and nesting phenotypes can be important to 
understand how polygenic mechanisms contribute to variation in compulsive expression and the implicated neural framework. Further, such strain comparisons can form the basis for dissecting how compulsivity diverges based on individual genetic variation largely contributing to clinical heterogeneity. Strain comparisons also allow drug response variations that can form the basis to examine differential treatment response rates often seen across patient subgroups. Such evaluations will enable a holistic approach toward understanding the pathophysiology. To this end we have conducted studies that have unveiled substantial understanding of how strain differences contribute to divergent phenotypic and drug response profiles in the compulsive condition.

For compulsive-like behaviors, the HA strains respond only to first line treatment options (140). There is dose-dependent attenuation of compulsive-like nesting and marble burying behaviors in the HA males treated with chronic fluoxetine and clomipramine (140), and fluvoxamine (145). However, desipramine, a tricyclic antidepressant which is not effective in treating OCD (307-310), also shows no significant effects on compulsive-like nesting and marble burying (140) indicating specificity and predictive validity of first line treatments for attenuating the compulsive-like phenotypes. Using an alternative first line drug results in differential behavioral outcomes pertaining to the compulsive-like domains. On being subjected to chronic regimen ( 2 weeks) of fluvoxamine a dose-dependent attenuation of nest-building is observed only in the HA1 but not in the HA3 males (145). For compulsive-like marble burying trait, fluvoxamine shows comparable results with overall dose-dependent decreases in marbles burying in both the strains. Currently there is no consensus on the best treatment option for OCD (30). Relapse rates with SSRIs are high in clinical populations (311). Medication differences have also been observed with these first-line treatments such as in children with OCD and comorbid tics, which reduces the efficacy of SSRI treatment (312). It is however unclear if the same effect is persistent in adults (313). Among various factors, compulsive traits and associated co-morbid symptoms can result in nonresponsiveness to treatments in the OCD condition $(88,314)$. Hence, a trait and dosage specific response to first-line therapies in the HA strains cannot be ruled out.

To better understand the role of strain and sex differences we have demonstrated that the HA strains exhibit strain and sex differences in expression of behaviors (143). When tested in the proestrus stage of the estrus cycle when the estrogen levels are thought to be higher in circulation, the HA1 and HA3 females exhibit less compulsive-like nest-building than the males, exhibiting a sex difference in expression of compulsivity. This sex difference is however retained only in the HA1 strains for marble burying behavior (143). The HA strains exhibit no strain differences in the open field. However, in the elevated plus maze the HA3 males explore the open arms more than the HA1 males while the female HA strains exhibit no such differences (143). Further, open arm explorations of both the HA females and HA1 males in the plus maze follow a negative correlation with the compulsive-like nest-building and marble burying behaviors (143). Such behavioral expression patterns are critical in delineating the different aspects of emotionality associated with anxiety that could be driven by sex and genotype interactions in the compulsive condition.

\section{ROLE OF PHYSIOLOGICAL STATE IN MODULATING COMPULSIVITY}

There is limited understanding as to how the physiological status that is largely driven by hormonal fluctuations influence OCD pathophysiology, which is especially relevant in women. With greater susceptibility of females for certain psychiatric disorders limited investigations have been conducted with contradictory results (315). One study has shown more prevalence of OCD during menopause (316), while another has demonstrated that the symptoms are more related to menarche and decrease during menopause (317). Acute conditions, such as surgical menopause, is more abrupt and can mimic natural menopause (318) leading to more drastic depletion of ovarian hormones precipitating mood and anxiety disorders (318). Interestingly, anti-compulsive effects of estradiol, allopregnanolone and progesterone have been established in animal studies (148, 263, 319, 320). When subjected to acute ovariectomy, exacerbation of compulsive-like and anxiety-like behaviors are observed in the compulsive-like female mice, but not in the CA control and LA strains, with a trait specific variation in compulsive-like behavior among the two female HA strains (141). This inter strain effect is abolished in the compulsive-like nest-building phenotype but not for marble burying once the ovariectomized strains were treated with either $17 \beta$-estradiol (E2) or progesterone (P4). Acute E2 administration attenuates compulsive-like nesting and marble burying, while P4 administration show no effect on these behaviors (141). For the anxiety-like measures a strain specific response to E2 and P4 administration is observed (141). Overall these behavioral attributes adhere to a complex heterogeneity (321-323) and reveals the interaction of genetic variation and sex hormones.

The post-partum condition is often associated with mood fluctuations and psychopathology and can precipitate OCD symptoms (324, 325). Physiologically, the brain undergoes dramatic shifts in hormonal milieu. This is often characterized by activation of oxytocinergic system in the paraventricular nucleus (PVN) and supraoptic nucleus (SON) regions of the hypothalamus due to suckling action (326-328). This leads to secretion of prolactin in the duct system. Since, both oxytocin and prolactin have functional roles in affective behaviors (329, 330), hindering the lactation process can alter cellular plasticity leading to mood disorders. This disruption can be further aggravated in patients with existing mental conditions such as OCD (331). However, the influence of post-partum condition on OCD symptomology is not known. Further, the neurobiological mechanisms underlying the interaction of post-partum phase and compulsivity is also unexplored. Using the HA1 strain we have also furthered the understanding of the role of oxytocin in influencing compulsive-, anxiety- and depression-like behaviors in post-partum condition. We have shown that oxytocin due to lactation is anti-compulsive during the post-partum phase 
and blocking oxytocin receptor exacerbate compulsive-like nestbuilding and marble burying behaviors during lactation (144). This behavioral modulation by oxytocin correlate with altered serotonin immunoreactivity in the dorsal raphe nucleus and enhanced responsiveness to fluoxetine. This indicates cross-talk between the oxytocin and the serotonergic signaling pathways during the compulsive-like condition and shows that suckling action may be beneficial during the post-partum condition (144). These findings provide critical insight into the putative role of oxytocin during physiologically challenging conditions such as post-partum phase warranting further investigation on the role of SSRI effectiveness.

\section{EFFECT OF NEW PHARMACOTHERAPIES AND PSYCHOSTIMULANTS IN THE SPONTANEOUS MOUSE MODEL}

There is evidence of cholinergic involvement in OCD (332, 333). OCD patients typically report less smoking behavior when compared to other neuropsychiatric disorders (334). It has been hypothesized that nicotine further activates the hyperactive fronto-striatal circuit resulting in exacerbation of symptoms. This is mainly through glutamate release by nicotinic receptor activation (334). This theory has however been challenged by other studies which have shown significant clinical improvements in OCD patients augmented with nicotine (335). Since cholinergic projections innervate the orbitofrontal cortex (336), which is one of the implicated regions in OCD $(229,337)$, further investigation is required to understand the modulatory role of cholinergic system in obsessive-compulsive behaviors. It was not until recently that cholinergic involvement was investigated in animal models of OCD. Selective ablation of striatal cholinergic interneurons results in repetitive behaviors concomitant with ritualistic social exploration in a transgenic mouse model (338). Congruently, we recently demonstrated that positive allosteric modulation of nicotinic receptor $\alpha 4 \beta 2$ subtype by a novel drug, desformylflustrabromine (dFBr), attenuates compulsive-like but not anxiety-like behaviors in the compulsive-like mouse model (142). The anti-compulsive dose-dependent effect of $\mathrm{dFBr}$ is observed in both acute and chronic administration regimens (142) indicating that targeting the $\alpha 4 \beta 2$ nicotinic receptor subtype could result in rapid remission of compulsivity and is a potential therapeutic area that requires attention.

Psychostimulants influence the pathophysiology of psychiatric disorders. With a surge in the unregulated usage of psychostimulants (339), animal models of psychiatric disorders should be investigated for their potential modulatory effects on behavioral expression. Considering the clinical heterogeneity among patient populations as discussed, it is feasible that psychostimulants will have differential effects among various patient subgroups. Caffeine is the most commonly used psychostimulant consumed by over $90 \%$ of the adult population and have several health enhancing effects (340). However, caffeine also causes cardiovascular disorders, sleep disturbances, and has an abuse liability (341). The specific role of caffeine in influencing obsessions and compulsions remains to be determined. In fact, OCD patients with comorbid bipolar disorders become easily addicted to caffeine indicating possible interactions between caffeine and OCD traits (342-345). Acute exposure to a high dose of caffeine reduces both nestbuilding and marble burying behavior in the compulsive-like HA strains (279). On the contrary, a chronic exposure of a high dose of caffeine increases nest-building behavior without influencing marble burying indicating trait and drug response heterogeneity (279).

\section{CONCLUSION}

One of the greatest challenges in OCD research has been to pinpoint neurobiological substrates and devise effective therapeutic measures targeting the same. Clinical heterogeneity (346) further compounds the problem resulting in higher drug resistance rates (37). Animal models to this end have been resourceful for identifying candidate genes that account for behavioral anomalies (203) and drugs of therapeutic value. However, much of the pre-clinical knowledge has not been successfully translated to the clinic. It is important to acknowledge that OCD is caused by a conglomeration of various factors (29). Hence, it becomes essential to account for those variables while selecting and testing an animal model. For example, strain comparisons can be critical in understanding heterogeneity in behavioral expression and drug responses that correlate to compulsive responses in humans. Rodent models such as the spontaneous compulsive-like nest-building mice exhibit variation in intensity of compulsive-like phenotypes. Many studies on animal models of OCD do not consider females when testing for face, predictive and construct validity. Sex differences play a vital role in the disease dimensions pertaining to onset, symptom patterns and associated comorbidities thereby accounting partially, if not completely, toward clinical heterogeneity. Further, physiologically challenging conditions such as puberty, pregnancy, post-partum and menopause modulate OCD. Future studies on both animals and humans should therefore consider sex differences and take into consideration the physiological stages for better evaluation of these factors in disease pathophysiology.

The spontaneous compulsive-like mice (HA strains) exhibit consistent, predictable and reproducible compulsive-like phenotypes across both sexes and provide a basis for investigating variables that might influence disease pathophysiology. Due to the established role of environmental influence in OCD, specific triggers such as prenatal infections, trauma and stress should be incorporated while subjecting animals to behavioral tests. For example, a multitude of studies have indicated that maternal immune activation result in exacerbation of compulsive-like marble burying behavior in offspring (347349). Further, inflammation interacts with genetic factors to potentiate behavioral impairments (350). Greater precedence is therefore needed to devise such model systems that look at gene-environment interactions in compulsive-like expression. The spontaneous compulsive-like mouse strains (HA strains), 
which were developed through bidirectional selection for nesting $(181,182)$, provide the unique opportunity to tap the interaction of such environmental and genetic factors $(140-145)$ as we have reviewed here.

OCD is often associated with social impairments and has been consistently reported in patient cohorts (351). It could therefore imply that in certain patient subsets the brain circuitries pertaining to social interaction and compulsivity is affected. Animal models should be evaluated for such complex paradigms where two or more behavioral domains are tested simultaneously. One study with the naturalistic deer mouse model showed deficits in social interactions that correlated with compulsive-like phenotypic expression (352). In another study, clomipramine exposure to immature rats resulted in increased anxiety, inflexibility in alternation and reversal learning, working memory deficit and hoarding (353). Similar exhaustive investigation with the spontaneous compulsivelike mouse model on multiple behavioral domains can reveal overlapping brain regions effected in OCD.

It is also critical to look beyond the boundaries of the rudimentary behaviors that have been defined in the literature. Inch-worming, a novel pattern of digging, has been reported in BTBR mice that can recapitulate compulsive behaviors in humans (354). With persistent digging commonly observed across the HA strains, micro-behaviors within a general behavioral domain can elucidate several aspects of repetitiveness. Time spent digging and patterned digging could provide a better representation of the behavioral attributes mediating compulsivity. Certain subsets of the compulsive-like HA mice also exhibit compulsive-like food shredding phenotype that is repetitive in nature (unpublished data). Such food grinding/shredding in captivity has been suggested to represent compulsive-like behavior $(355,356)$ and varies considerably based on environmental factors such as diet and enrichments. Food shredding is observed in a subset of mice of the compulsivelike strains and the role of genetics, such as founder effects and genetic drift $(181,182)$, cannot be ruled out. Hence food shredding can be utilized as a novel compulsive-like phenotype to understand the role of gene-environmental interactions.

Like every other model of compulsive-like behaviors the spontaneous mouse strains also have some limitations. The compulsive-like HA strains do not exhibit pathological grooming behavior, a phenotype common to several spontaneous, gene knockout and drug-induced OCD models. Moreover, the putative polygenic factors driving such transgenerational compulsive-like phenotypes are unknown. This however does

\section{REFERENCES}

1. Karno M, Golding JM, Sorenson SB, Burnam MA. The epidemiology of obsessive-compulsive disorder in five US communities. Arch Gen Psychiatry. (1988) 45:1094-9. doi: 10.1001/archpsyc.1988.01800360042006

2. Soomro GM. Obsessive compulsive disorder. BMJ Clin Evid. (2012).

3. Kessler RC, Berglund P, Demler O, Jin R, Merikangas KR, Walters EE. Lifetime prevalence and age-of-onset distributions of DSM-IV disorders in the National Comorbidity Survey Replication. Arch Gen Psychiatry. (2005) 62:593-602. doi: 10.1001/archpsyc.62.6.593 not take away the importance of these strains in providing critical insight into the heterogeneity of repetitive behaviors and differential drug responses that are modulated by gene, environment and sex interactions. Further, identifying genes regulating these repetitive nesting and burying behaviors through modern genomic approaches can divulge new targets previously unidentified and linked to the pathophysiology of OCD.

Finally, we have demonstrated in this review that artificial bidirectional selection for a normal behavior, i.e., nest-building behavior, resulted in the creation of a spontaneous, stable and predictable compulsive-like phenotype that has face, predictive, and construct validity for studying various aspects of OCD in humans. Specifically, construct validity (201) has been established by desipramine having no effect on compulsivelike nest-building behavior (140) and the involvement of the serotonergic $(140,145,357)$, cholinergic (142), estrogenic (141), oxytocinergic (144), and GABAergic neurotransmitter pathways (357). In addition, the use of these selected strains resulted in the identification of an entirely new class of drugs for attenuating compulsivity, i.e., drugs that affect the nicotinic receptor $\alpha 4 \beta 2$ subtype as shown with $\mathrm{dFBr}$, a positive allosteric modulator of these receptors (142). Importantly, $\mathrm{dFBr}$ is effective within $2 \mathrm{~h}$ and reduces compulsive-like behaviors up to $90 \%$ (142). Therefore, the use of artificially selected mouse strains for compulsive-like behaviors represent an alternative strategy to study OCD and OCRD that has great potential.

\section{AUTHOR CONTRIBUTIONS}

SM wrote the first draft of the manuscript. AB-I made extensive revisions of the manuscript. All authors contributed to the article and approved the submitted version.

\section{FUNDING}

The research reported in this publication on the spontaneous, stable and predictable compulsive-like behavioral phenotype was funded by grants from the National Institute of General Medical Sciences of the National Institutes of Health (1) under an Institutional Development Award (IDeA; Grant Number P20GM103395) and (2) under a Building Infrastructure Leading to Diversity Award (BUILD; three linked Grants Numbered RL5GM118990, TL4GM118992, and 1UL1GM118991). The Department of Biology and Wildlife and the Department of Chemistry and Biochemistry at the University of Alaska Fairbanks also supported this work.
4. Ruscio AM, Stein DJ, Chiu WT, Kessler RC. The epidemiology of obsessivecompulsive disorder in the National Comorbidity Survey Replication. Mol Psychiatry. (2010) 15:53-63. doi: 10.1038/mp.2008.94

5. Jaisoorya TS, Janardhan Reddy YC, Nair BS, Rani A, Menon PG, Revamma M, et al. Prevalence and correlates of obsessivecompulsive disorder and subthreshold obsessive-compulsive disorder among college students in Kerala, India. Indian J Psychiatry. (2017) 59:56-62. doi: 10.4103/0019-5545.204438

6. Skapinakis P, Bellos S, Koupidis S, Grammatikopoulos I, Theodorakis $\mathrm{PN}$, Mavreas V. Prevalence and sociodemographic associations of 
common mental disorders in a nationally representative sample of the general population of Greece. BMC Psychiatry. (2013) 13:163. doi: $10.1186 / 1471-244 \mathrm{X}-13-163$

7. Janet P. Les Obsessions et la psychasthénie. Paris:Alcan (1903).

8. Pitman RK. Pierre Janet on obsessive-compulsive disorder (1903). Review and commentary. Arch Gen Psychiatry. (1987) 44:226-32. doi: 10.1001/archpsyc.1987.01800150032005

9. Ayuso-Mateos J. Global Burden of Obsessive-Compulsive Disorder in the year 2000. Geneva: World Health Organization (2006).

10. Murray CJL, Lopez AD, World Health Orgination, World B, Harvard School of Public H. The Global Burden of Disease: A Comprehensive Assessment of Mortality and Disability from Diseases, Injuries, and Risk Factors in 1990 and Projected to 2020: Summary. Christopher J, Murray Alan L, Lopez D. Geneva: World Health Organization (1996).

11. Dupont RL, Rice DP, Shiraki S, Rowland CR. Economic costs of obsessivecompulsive disorder. Med Interface. (1995) 8:102-9.

12. Bobes J, Gonzalez MP, Bascaran MT, Arango C, Saiz PA, Bousono M. Quality of life and disability in patients with obsessive-compulsive disorder. Eur Psychiatry. (2001) 16:239-45. doi: 10.1016/S0924-9338(01)00571-5

13. Chaudhury PK, Deka K, Chetia D. Disability associated with mental disorders. Indian $J$ Psychiatry. (2006) 48:95101. doi: 10.4103/0019-5545.31597

14. Markarian Y, Larson MJ, Aldea MA, Baldwin SA, Good D, Berkeljon A, et al. Multiple pathways to functional impairment in obsessive-compulsive disorder. Clin Psychol Rev. (2010) 30:78-88. doi: 10.1016/j.cpr.2009.09.005

15. Jacoby RJ, Leonard RC, Riemann BC, Abramowitz JS. Predictors of quality of life and functional impairment in obsessive-compulsive disorder. Compr Psychiatry. (2014) 55:1195-202. doi: 10.1016/j.comppsych.2014.03.011

16. Storch EA, Wu MS, Small BJ, Crawford EA, Lewin AB, Horng B, et al. Mediators and moderators of functional impairment in adults with obsessive-compulsive disorder. Compr Psychiatry. (2014) 55:48996. doi: 10.1016/j.comppsych.2013.10.014

17. Coluccia A, Fagiolini A, Ferretti F, Pozza A, Costoloni G, Bolognesi S, et al. Adult obsessive-compulsive disorder and quality of life outcomes: a systematic review and meta-analysis. Asian J Psychiatr. (2016) 22:4152. doi: 10.1016/j.ajp.2016.02.001

18. Schwartzman CM, Boisseau CL, Sibrava NJ, Mancebo MC, Eisen JL, Rasmussen SA. Symptom subtype and quality of life in obsessive-compulsive disorder. Psychiatry Res. (2017) 249:307-10. doi: 10.1016/j.psychres.2017.01.025

19. Velloso P, Piccinato C, Ferrao Y, Perin EA, Cesar R, Fontenelle LF, et al. Clinical predictors of quality of life in a large sample of adult obsessive-compulsive disorder outpatients. Compr Psychiatry. (2018) 86:8290. doi: 10.1016/j.comppsych.2018.07.007

20. Altamura AC, Buoli M, Albano A, Dell'osso B. Age at onset and latency to treatment (duration of untreated illness) in patients with mood and anxiety disorders: a naturalistic study. Int Clin Psychopharmacol. (2010) 25:172-9. doi: 10.1097/YIC.0b013e3283384c74

21. Dell'osso B, Camuri G, Benatti B, Buoli M, Altamura AC. Differences in latency to first pharmacological treatment (duration of untreated illness) in anxiety disorders: a study on patients with panic disorder, generalized anxiety disorder and obsessive-compulsive disorder. Early Interv Psychiatry. (2013) 7:374-80. doi: 10.1111/eip.12016

22. Postlethwaite A, Kellett S, Mataix-Cols D. Prevalence of hoarding disorder: a systematic review and meta-analysis. J Affect Disord. (2019) 256:30916. doi: $10.1016 /$ j.jad.2019.06.004

23. Abramowitz JS, Taylor S, Mckay D. Obsessive-compulsive disorder. Lancet. (2009) 374:491-9. doi: 10.1016/S0140-6736(09)60240-3

24. Fullana MA, Mataix-Cols D, Caspi A, Harrington H, Grisham JR, Moffitt TE, et al. Obsessions and compulsions in the community: prevalence, interference, help-seeking, developmental stability, and cooccurring psychiatric conditions. Am J Psychiatry. (2009) 166:32936. doi: 10.1176/appi.ajp.2008.08071006

25. Marazziti D, Carlini M, Dell'osso L. Treatment strategies of obsessivecompulsive disorder and panic disorder/agoraphobia. Curr Top Med Chem. (2012) 12:238-53. doi: 10.2174/1568026799078688

26. Mckay D, Abramowitz JS, Calamari JE, Kyrios M, Radomsky A, Sookman D, et al. A critical evaluation of obsessive-compulsive disorder subtypes: symptoms versus mechanisms. Clin Psychol Rev. (2004) 24:283313. doi: $10.1016 /$ j.cpr.2004.04.003

27. Lombroso PJ, Scahill L. Tourette syndrome and obsessive-compulsive disorder. Brain Dev. (2008) 30:231-7. doi: 10.1016/j.braindev.2007.09.001

28. Thomsen PH. Obsessive-compulsive disorders. Eur Child Adolesc Psychiatry. (2013) 22(Suppl. 1):S23-28. doi: 10.1007/s00787-012-0357-7

29. Pauls DL, Abramovitch A, Rauch SL, Geller DA. Obsessive-compulsive disorder: an integrative genetic and neurobiological perspective. Nat Rev Neurosci. (2014) 15:410-24. doi: 10.1038/nrn3746

30. Hirschtritt ME, Bloch MH, Mathews CA. Obsessive-compulsive disorder: advances in diagnosis and treatment. JAMA. (2017) 317:1358-67. doi: 10.1001/jama.2017.2200

31. Grant JE. Obsessive-compulsive disorder. N Engl J Med. (2014) 371:64653. doi: 10.1056/NEJMcp1402176

32. Goodman WK, Price LH, Rasmussen SA, Mazure C, Fleischmann RL, Hill CL, et al. The Yale-Brown obsessive compulsive scale. I Development, use, and reliability. Arch Gen Psychiatry. (1989) 46:100611. doi: 10.1001/archpsyc. 1989.01810110048007

33. Rosario-Campos MC, Miguel EC, Quatrano S, Chacon P, Ferrao Y, Findley D, et al. The Dimensional Yale-Brown obsessive-compulsive scale (DY-BOCS): an instrument for assessing obsessive-compulsive symptom dimensions. Mol Psychiatry. (2006) 11:495-504. doi: 10.1038/sj.mp.4001798

34. Okada K, Nakao T, Sanematsu H, Murayama K, Honda S, Tomita M, et al. Biological heterogeneity of obsessive-compulsive disorder: a voxelbased morphometric study based on dimensional assessment. Psychiatry Clin Neurosci. (2015) 69:411-21. doi: 10.1111/pcn.12269

35. Hasler G, Lasalle-Ricci VH, Ronquillo JG, Crawley SA, Cochran LW, Kazuba $\mathrm{D}$, et al. Obsessive-compulsive disorder symptom dimensions show specific relationships to psychiatric comorbidity. Psychiatry Res. (2005) 135:12132. doi: 10.1016/j.psychres.2005.03.003

36. Mataix-Cols D, Rosario-Campos MC, Leckman JF. A multidimensional model of obsessive-compulsive disorder. Am J Psychiatry. (2005) 162:22838. doi: 10.1176/appi.ajp.162.2.228

37. Miguel EC, Leckman JF, Rauch S, Do Rosario-Campos MC, Hounie AG, Mercadante MT, et al. Obsessive-compulsive disorder phenotypes: implications for genetic studies. Mol Psychiatry. (2005) 10:258-75. doi: 10.1038/sj.mp.4001617

38. Catapano F, Perris F, Fabrazzo M, Cioffi V, Giacco D, De Santis V, et al. Obsessive-compulsive disorder with poor insight: a three-year prospective study. Prog Neuropsychopharmacol Biol Psychiatry. (2010) 34:323-30. doi: 10.1016/j.pnpbp.2009.12.007

39. Katerberg H, Delucchi KL, Stewart SE, Lochner C, Denys DA, Stack DE, et al. Symptom dimensions in OCD: item-level factor analysis and heritability estimates. Behav Genet. (2010) 40:505-17. doi: 10.1007/s10519-010-9339-z

40. Torresan RC, Ramos-Cerqueira AT, Shavitt RG, Do Rosario MC, De Mathis MA, Miguel EC, et al. Symptom dimensions, clinical course and comorbidity in men and women with obsessive-compulsive disorder. Psychiatry Res. (2013) 209:186-95. doi: 10.1016/j.psychres.2012.12.006

41. Mccarty RJ, Guzick AG, Swan LK, McNamara JPH. Stigma and recognition of different types of symptoms in OCD. J Obsess Compul Relat Disord. (2017) 12:64-70. doi: 10.1016/j.jocrd.2016.12.006

42. Jenike MA. Neurosurgical treatment of obsessive-compulsive disorder. $\mathrm{Br} \mathrm{J}$ Psychiatry Suppl. (1998) 35:79-90. doi: 10.1192/S0007125000297936

43. Pigott TA, Seay SM. A review of the efficacy of selective serotonin reuptake inhibitors in obsessive-compulsive disorder. J Clin Psychiatry. (1999) 60:1016. doi: 10.4088/JCP.v60n0206

44. Jenike MA. Clinical practice. Obsess-compulsive disorder. N Engl J Med. (2004) 350:259-65. doi: 10.1056/NEJMcp031002

45. Geller DA, Biederman J, Jones J, Shapiro S, Schwartz S, Park KS. Obsessivecompulsive disorder in children and adolescents: a review. Harv Rev Psychiatry. (1998) 5:260-73. doi: 10.3109/10673229809000309

46. Zohar AH. The epidemiology of obsessive-compulsive disorder in children and adolescents. Child Adolesc Psychiatr Clin N Am. (1999) 8:44560. doi: 10.1016/S1056-4993(18)30163-9

47. Nakatani E, Krebs G, Micali N, Turner C, Heyman I, Mataix-Cols D. Children with very early onset obsessive-compulsive disorder: clinical features and treatment outcome. J Child Psychol Psychiatry. (2011) 52:12618. doi: $10.1111 / \mathrm{j} .1469-7610.2011 .02434 . \mathrm{x}$ 
48. Kalra SK, Swedo SE. Children with obsessive-compulsive disorder: are they just "little adults" J Clin Invest. (2009) 119:737-46. doi: 10.1172/JCI37563

49. Shugart YY, Samuels J, Willour VL, Grados MA, Greenberg BD, Knowles JA, et al. Genomewide linkage scan for obsessive-compulsive disorder: evidence for susceptibility loci on chromosomes 3q, 7p, 1q, 15q, and 6q. Mol Psychiatry. (2006) 11:763-70. doi: 10.1038/sj.mp.4001847

50. Hanna GL, Veenstra-Vanderweele J, Cox NJ, Van Etten M, Fischer DJ, Himle JA, et al. Evidence for a susceptibility locus on chromosome 10p15 in early-onset obsessive-compulsive disorder. Biol Psychiatry. (2007) 62:85662. doi: 10.1016/j.biopsych.2007.01.008

51. Samuels J, Shugart YY, Grados MA, Willour VL, Bienvenu OJ, Greenberg $\mathrm{BD}$, et al. Significant linkage to compulsive hoarding on chromosome 14 in families with obsessive-compulsive disorder: results from the OCD collaborative genetics study. Am J Psychiatry. (2007) 164:4939. doi: 10.1176/ajp.2007.164.3.493

52. Mathews CA, Badner JA, Andresen JM, Sheppard B, Himle JA, Grant JE, et al. Genome-wide linkage analysis of obsessive-compulsive disorder implicates chromosome 1p36. Biol Psychiatry. (2012) 72:629-36. doi: 10.1016/j.biopsych.2012.03.037

53. Stewart SE, Mayerfeld C, Arnold PD, Crane JR, O'dushlaine C, Fagerness $\mathrm{JA}$, et al. Meta-analysis of association between obsessive-compulsive disorder and the 3' region of neuronal glutamate transporter gene SLC1A1. Am J Med Genet B Neuropsychiatr Genet. (2013) 162b:36779. doi: 10.1002/ajmg.b.32137

54. Taylor S. Molecular genetics of obsessive-compulsive disorder: a comprehensive meta-analysis of genetic association studies. Mol Psychiatry. (2013) 18:799-805. doi: 10.1038/mp.2012.76

55. American Psychiatric Association. Diagnostic and Statistical Manual of Mental Disorders. Arlingon, VA: American Psychiatric Publishing (2013).

56. Fornaro M, Gabrielli F, Albano C, Fornaro S, Rizzato S, Mattei C, et al. Obsessive-compulsive disorder and related disorders: a comprehensive survey. Ann Gen Psychiatry. (2009) 8:13. doi: 10.1186/1744-859X-8-13

57. Bohne A, Keuthen N, Wilhelm S. Pathologic hairpulling, skin picking, and nail biting. Ann Clin Psychiatry. (2005) 17:227-32. doi: 10.1080/10401230500295354

58. Tucker BT, Woods DW, Flessner CA, Franklin SA, Franklin ME. The skin picking impact project: phenomenology, interference, and treatment utilization of pathological skin picking in a population-based sample. $J$ Anxiety Disord. (2011) 25:88-95. doi: 10.1016/j.janxdis.2010.08.007

59. Selles RR, Mcguire JF, Small BJ, Storch EA. A systematic review and meta-analysis of psychiatric treatments for excoriation (skin-picking) disorder. Gen Hosp Psychiatry. (2016) 41:2937. doi: 10.1016/j.genhosppsych.2016.04.001

60. Lochner C, Roos A, Stein DJ. Excoriation (skin-picking) disorder: a systematic review of treatment options. Neuropsychiatr Dis Treat. (2017) 13:1867-72. doi: 10.2147/NDT.S121138

61. Houghton DC, Alexander JR, Bauer CC, Woods DW. Body-focused repetitive behaviors: more prevalent than once thought? Psychiatry Res. (2018) 270:389-93. doi: 10.1016/j.psychres.2018.10.002

62. Grant JE, Chamberlain SR. Prevalence of skin picking (excoriation) disorder. J Psychiatr Res. (2020) 130:57-60. doi: 10.1016/j.jpsychires.2020.06.033

63. Shoenfeld N, Rosenberg O, Kotler M, Dannon PN. Tricotillomania: pathopsychology theories and treatment possibilities. Isr Med Assoc J. (2012) 14:125-9.

64. Woods DW, Houghton DC. Diagnosis, evaluation, and management of trichotillomania. Psychiatr Clin North Am. (2014) 37:301-17. doi: 10.1016/j.psc.2014.05.005

65. Grant JE, Redden SA, Leppink EW, Chamberlain SR. Trichotillomania and co-occurring anxiety. Compr Psychiatry. (2017) 72:15. doi: 10.1016/j.comppsych.2016.09.005

66. Pereyra AD, Saadabadi A. Trichotillomania. Treasure Island, FL: StatPearls (2018).

67. Grant JE, Dougherty DD, Chamberlain SR. Prevalence, gender correlates, and co-morbidity of trichotillomania. Psychiatry Res. (2020) 288:112948. doi: $10.1016 /$ j.psychres.2020.112948

68. Halteh P, Scher RK, Lipner SR. Onychotillomania: diagnosis and management. Am J Clin Dermatol. (2017) 18:76370. doi: $10.1007 /$ s40257-017-0289-6
69. Phillips KA. Body dysmorphic disorder: the distress of imagined ugliness. Am J Psychiatry. (1991) 148:1138-49. doi: 10.1176/ajp.148.9.1138

70. Phillipou A, Castle D. Body dysmorphic disorder in men. Aust Fam Physician. (2015) 44:798-801. doi: 10.3316/informit.585209858722018

71. Ahluwalia R, Bhatia NK, Kumar PS, Kaur P. Body dysmorphic disorder: diagnosis, clinical aspects and treatment strategies. Indian J Dent Res. (2017) 28:193-7. doi: 10.4103/ijdr.IJDR_669_15

72. Krebs G, Fernandez De La Cruz L, Mataix-Cols D. Recent advances in understanding and managing body dysmorphic disorder. Evid Based Ment Health. (2017) 20:71-5. doi: 10.1136/eb-2017-102702

73. Enander J, Ivanov VZ, Mataix-Cols D, Kuja-Halkola R, Ljótsson B, Lundström S, et al. Prevalence and heritability of body dysmorphic symptoms in adolescents and young adults: a population-based nationwide twin study. Psychol Med. (2018) 48:2740-7. doi: 10.1017/S0033291718000375

74. Hong K, Nezgovorova V, Hollander E. New perspectives in the treatment of body dysmorphic disorder. F1000Res. (2018) 7:361. doi: 10.12688/f1000research.13700.1

75. Johnson S, Williamson P, Wade TD. A systematic review and meta-analysis of cognitive processing deficits associated with body dysmorphic disorder. Behav Res Ther. (2018) 107:83-94. doi: 10.1016/j.brat.2018.05.013

76. Singh AR, Veale D. Understanding and treating body dysmorphic disorder. Indian J Psychiatry. (2019) 61:S1315. doi: 10.4103/psychiatry.IndianJPsychiatry_528_18

77. Wu KD, Watson D. Hoarding and its relation to obsessive-compulsive disorder. Behav Res Ther. (2005) 43:897-921. doi: 10.1016/j.brat.2004.06.013

78. Labad J, Alonso P, Segalas C, Real E, Jimenez S, Bueno B, et al. Distinct correlates of hoarding and cleaning symptom dimensions in relation to onset of obsessive-compulsive disorder at menarche or the perinatal period. Arch Womens Ment Health. (2010) 13:75-81. doi: 10.1007/s00737-009-0098-x

79. Tolin DF. Understanding and treating hoarding: a biopsychosocial perspective. J Clin Psychol. (2011) 67:517-26. doi: 10.1002/jclp.20795

80. Neziroglu F, Weissman S, Allen J, Mckay D. Compulsive hoarders: how do they differ from individuals with obsessive compulsive disorder? Psychiatry Res. (2012) 200:35-40. doi: 10.1016/j.psychres.2012.04.002

81. Morris SH, Jaffee SR, Goodwin GP, Franklin ME. Hoarding in children and adolescents: a review. Child Psychiatry Hum Dev. (2016) 47:74050. doi: 10.1007/s10578-015-0607-2

82. Williams M, Viscusi JA. Hoarding disorder and a systematic review of treatment with cognitive behavioral therapy. Cogn Behav Ther. (2016) 45:93110. doi: 10.1080/16506073.2015.1133697

83. Overbeek T, Schruers K, Vermetten E, Griez E. Comorbidity of obsessive-compulsive disorder and depression: prevalence, symptom severity, and treatment effect. J Clin Psychiatry. (2002) 63:1106-12. doi: 10.4088/JCP.v63n1204

84. Tükel R, Polat A, Ozdemir O, Aksüt D, Türksoy N. Comorbid conditions in obsessive-compulsive disorder. Compr Psychiatry. (2002) 43:2049. doi: 10.1053/comp.2002.32355

85. Torres AR, Prince MJ, Bebbington PE, Bhugra D, Brugha TS, Farrell M, et al. Obsessive-compulsive disorder: prevalence, comorbidity, impact, and helpseeking in the British National Psychiatric Morbidity Survey of 2000. Am J Psychiatry. (2006) 163:1978-85. doi: 10.1176/ajp.2006.163.11.1978

86. Boileau B. A review of obsessive-compulsive disorder in children and adolescents. Dialogues Clin Neurosci. (2011) 13:401-11. doi: 10.31887/DCNS.2011.13.4/bboileau

87. Murphy DL, Timpano KR, Wheaton MG, Greenberg BD, Miguel EC. Obsessive-compulsive disorder and its related disorders: a reappraisal of obsessive-compulsive spectrum concepts. Dialogues Clin Neurosci. (2010) 12:131-48. doi: 10.31887/DCNS.2010.12.2/dmurphy

88. Pallanti S, Grassi G, Sarrecchia ED, Cantisani A, Pellegrini M. Obsessivecompulsive disorder comorbidity: clinical assessment and therapeutic implications. Front Psychiatry. (2011) 2:70. doi: 10.3389/fpsyt.2011.00070

89. De Mathis MA, Diniz JB, Hounie AG, Shavitt RG, Fossaluza V, Ferrao Y, et al. Trajectory in obsessive-compulsive disorder comorbidities. Eur Neuropsychopharmacol. (2013) 23:594601. doi: 10.1016/j.euroneuro.2012.08.006

90. Murphy DL, Moya PR, Fox MA, Rubenstein LM, Wendland JR, Timpano KR. Anxiety and affective disorder comorbidity related to serotonin and other neurotransmitter systems: obsessive-compulsive disorder as an 
example of overlapping clinical and genetic heterogeneity. Philos Trans $R$ Soc Lond B Biol Sci. (2013) 368:20120435. doi: 10.1098/rstb.2012.0435

91. Cuzen NL, Stein DJ, Lochner C, Fineberg NA. Comorbidity of obsessivecompulsive disorder and substance use disorder: a new heuristic. Hum Psychopharmacol. (2014) 29:89-93. doi: 10.1002/hup.2373

92. Lochner C, Fineberg NA, Zohar J, Van Ameringen M, Juven-Wetzler A, Altamura AC, et al. Comorbidity in obsessive-compulsive disorder $(\mathrm{OCD})$ : a report from the International College of ObsessiveCompulsive Spectrum Disorders (ICOCS). Compr Psychiatry. (2014) 55:1513-9. doi: 10.1016/j.comppsych.2014.05.020

93. Campos LM, Yoshimi NT, Simao MO, Torresan RC, Torres AR. Obsessive-compulsive symptoms among alcoholics in outpatient treatment: prevalence, severity and correlates. Psychiatry Res. (2015) 229:4019. doi: 10.1016/j.psychres.2015.05.111

94. Goodwin GM. The overlap between anxiety, depression, and obsessive-compulsive disorder. Dialogues Clin Neurosci. (2015) 17:249-60. doi: 10.31887/DCNS.2015.17.3/ggoodwin

95. Figee $M$, Pattij T, Willuhn I, Luigjes J, Van Den Brink W, Goudriaan A, et al. Compulsivity in obsessive-compulsive disorder and addictions. Eur Neuropsychopharmacol. (2016) 26:856-68. doi: 10.1016/j.euroneuro.2015.12.003

96. Ortiz AE, Morer A, Moreno E, Plana MT, Cordovilla C, Lazaro L. Clinical significance of psychiatric comorbidity in children and adolescents with obsessive-compulsive disorder: subtyping a complex disorder. Eur Arch Psychiatry Clin Neurosci. (2016) 266:199-208. doi: 10.1007/s00406-015-0642-9

97. Torres AR, Fontenelle LF, Shavitt RG, Ferrao YA, Do Rosario MC, Storch EA, et al. Comorbidity variation in patients with obsessive-compulsive disorder according to symptom dimensions: results from a large multicentre clinical sample. J Affect Disord. (2016) 190:508-16. doi: 10.1016/j.jad.2015.10.051

98. Osland S, Arnold PD, Pringsheim T. The prevalence of diagnosed obsessive compulsive disorder and associated comorbidities: a population-based Canadian study. Psychiatry Res. (2018) 268:137-42. doi: 10.1016/j.psychres.2018.07.018

99. Ting JT, Feng G. Glutamatergic synaptic dysfunction and obsessive-compulsive disorder. Curr Chem Genomics. (2008) 2:62-75. doi: $10.2174 / 1875397300802010062$

100. Krebs G, Heyman I. Obsessive-compulsive disorder in children and adolescents. Arch Dis Child. (2015) 100:4959. doi: 10.1136/archdischild-2014-306934

101. Alsobrook IJ, Leckman JF, Goodman WK, Rasmussen SA, Pauls DL. Segregation analysis of obsessive-compulsive disorder using symptom-based factor scores. Am J Med Genet. (1999) 88:66975. doi: 10.1002/(SICI) 1096-8628(19991215)88:6<669::AID-AJMG17>3.0. $\mathrm{CO} ; 2-\mathrm{N}$

102. Nestadt G, Lan T, Samuels J, Riddle M, Bienvenu OJ, III, Liang KY, Hoehn-Saric R, et al. Complex segregation analysis provides compelling evidence for a major gene underlying obsessive-compulsive disorder and for heterogeneity by sex. Am J Hum Genet. (2000) 67:16116. doi: $10.1086 / 316898$

103. Nicolini H, Arnold P, Nestadt G, Lanzagorta N, Kennedy JL. Overview of genetics and obsessive-compulsive disorder. Psychiatry Res. (2009) 170:714. doi: 10.1016/j.psychres.2008.10.011

104. Jonnal AH, Gardner CO, Prescott CA, Kendler KS. Obsessive and compulsive symptoms in a general population sample of female twins. Am J Med Genet. (2000) 96:7916. doi: 10.1002/1096-8628(20001204)96:6<791::AID-AJMG19>3.0.CO;2-C

105. Van Grootheest DS, Cath DC, Beekman AT, Boomsma DI. Twin studies on obsessive-compulsive disorder: a review. Twin Res Hum Genet. (2005) 8:450-8. doi: 10.1375/twin.8.5.450

106. Van Grootheest DS, Boomsma DI, Hettema JM, Kendler KS. Heritability of obsessive-compulsive symptom dimensions. Am J Med Genet B Neuropsychiatr Genet. (2008) 147B:473-8. doi: 10.1002/ajmg.b. 30622

107. Hollander E, Kwon JH, Stein DJ, Broatch J, Rowland CT, Himelein CA. Obsessive-compulsive and spectrum disorders: overview and quality of life issues. J Clin Psychiatry. (1996) 57(Suppl. 8):3-6.
108. Reinblatt SP, Riddle MA. The pharmacological management of childhood anxiety disorders: a review. Psychopharmacology (Berl). (2007) 191:6786. doi: $10.1007 / \mathrm{s} 00213-006-0644-4$

109. Ravindran AV, Da Silva TL, Ravindran LN, Richter MA, Rector NA. Obsessive-compulsive spectrum disorders: a review of the evidence-based treatments. Can J Psychiatry. (2009) 54:331-43. doi: 10.1177/070674370905400507

110. Bloch MH, Mcguire J, Landeros-Weisenberger A, Leckman JF, Pittenger C. Meta-analysis of the dose-response relationship of SSRI in obsessive-compulsive disorder. Mol Psychiatry. (2010) 15:850-5. doi: $10.1038 / \mathrm{mp} .2009 .50$

111. Kellner M. Drug treatment of obsessive-compulsive disorder. Dialogues Clin Neurosci. (2010) 12:187-97. doi: 10.31887/DCNS.2010.12.2/mkellner

112. Kariuki-Nyuthe C, Gomez-Mancilla B, Stein DJ. Obsessive compulsive disorder and the glutamatergic system. Curr Opin Psychiatry. (2014) 27:327. doi: $10.1097 /$ YCO. 0000000000000017

113. Odlaug BL, Weinhandl E, Mancebo MC, Mortensen EL, Eisen JL, Rasmussen SA, et al. Excluding the typical patient: thirty years of pharmacotherapy efficacy trials for obsessive-compulsive disorder. Ann Clin Psychiatry. (2014) 26:39-46.

114. Pittenger C, Bloch MH. Pharmacological treatment of obsessivecompulsive disorder. Psychiatr Clin North Am. (2014) 37:37591. doi: $10.1016 /$ j.psc.2014.05.006

115. Seibell PJ, Hollander E. Management of obsessive-compulsive disorder. F1000Prime Rep. (2014) 6:68. doi: 10.12703/P6-68

116. Castle D, Bosanac P, Rossell S. Treating OCD: what to do when first-line therapies fail. Australas Psychiatry. (2015) 23:350-3. doi: 10.1177/1039856215590027

117. Ivarsson T, Skarphedinsson G, Kornor H, Axelsdottir B, Biedilae S, Heyman I, et al. The place of and evidence for serotonin reuptake inhibitors (SRIs) for obsessive compulsive disorder (OCD) in children and adolescents: views based on a systematic review and meta-analysis. Psychiatry Res. (2015) 227:93-103. doi: 10.1016/j.psychres.2015.01.015

118. Kameg KM, Richardson L, Szpak JL. Pediatric obsessive-compulsive disorder: an update for advanced practice psychiatric nurses. J Child Adolesc Psychiatr Nurs. (2015) 28:84-91. doi: 10.1111/jcap.12111

119. Pittenger C. Glutamatergic agents for OCD and related disorders. Curr Treat Options Psychiatry. (2015) 2:271-83. doi: 10.1007/s40501-015-0051-8

120. Skapinakis P, Caldwell D, Hollingworth W, Bryden P, Fineberg N, Salkovskis $\mathrm{P}$, et al. A systematic review of the clinical effectiveness and cost-effectiveness of pharmacological and psychological interventions for the management of obsessive-compulsive disorder in children/adolescents and adults. Health Technol Assess. (2016) 20:1-392. doi: 10.3310/hta20430

121. Skapinakis P, Caldwell DM, Hollingworth W, Bryden P, Fineberg NA, Salkovskis $\mathrm{P}$, et al. Pharmacological and psychotherapeutic interventions for management of obsessive-compulsive disorder in adults: a systematic review and network meta-analysis. Lancet Psychiatry. (2016) 3:7309. doi: 10.1016/S2215-0366(16)30069-4

122. Locher C, Koechlin H, Zion SR, Werner C, Pine DS, Kirsch I, et al. Efficacy and safety of selective serotonin reuptake inhibitors, serotonin-norepinephrine reuptake inhibitors, and placebo for common psychiatric disorders among children and adolescents: a systematic review and meta-analysis. JAMA Psychiatry. (2017) 74:1011-20. doi: 10.1001/jamapsychiatry.2017.2432

123. Marinova Z, Chuang DM, Fineberg N. Glutamate-modulating drugs as a potential therapeutic strategy in obsessivecompulsive disorder. Curr Neuropharmacol. (2017) 15:97795. doi: 10.2174/1570159X15666170320104237

124. Grassi G, Pallanti S. Current and up-and-coming pharmacotherapy for obsessive-compulsive disorder in adults. Expert Opin Pharmacother. (2018) 19:1541-50. doi: 10.1080/14656566.2018.1528230

125. Pittenger C. Glutamate modulators in the treatment of obsessive-compulsive disorder. Psychiatr Ann. (2015) 45:30815. doi: 10.3928/00485713-20150602-06

126. Nestadt G, Grados M, Samuels JF. Genetics of obsessivecompulsive disorder. Psychiatr Clin North Am. (2010) 33:14158. doi: 10.1016/j.psc.2009.11.001 
127. Pauls DL. The genetics of obsessive-compulsive disorder: a review. Dialogues Clin Neurosci. (2010) 12:149-63. doi: 10.31887/DCNS.2010.12.2/dpauls

128. Bhattacharyya S, Chakraborty K. Glutamatergic dysfunction-newer targets for anti-obsessional drugs. Recent Pat CNS Drug Discov. (2007) 2:4755. doi: 10.2174/157488907779561727

129. Pittenger C, Bloch MH, Williams K. Glutamate abnormalities in obsessive compulsive disorder: neurobiology, pathophysiology, and treatment. Pharmacol Ther. (2011) 132:314-32. doi: 10.1016/j.pharmthera.2011.09.006

130. Wu K, Hanna GL, Rosenberg DR, Arnold PD. The role of glutamate signaling in the pathogenesis and treatment of obsessive-compulsive disorder. Pharmacol Biochem Behav. (2012) 100:726-35. doi: 10.1016/j.pbb.2011.10.007

131. Wu K, Hanna GL, Easter P, Kennedy JL, Rosenberg DR, Arnold PD. Glutamate system genes and brain volume alterations in pediatric obsessivecompulsive disorder: a preliminary study. Psychiatry Res. (2013) 211:21420. doi: 10.1016/j.pscychresns.2012.07.003

132. Simpson HB, Kegeles LS, Hunter L, Mao X, Van Meter P, Xu X, et al. Assessment of glutamate in striatal subregions in obsessive-compulsive disorder with proton magnetic resonance spectroscopy. Psychiatry Res. (2015) 232:65-70. doi: 10.1016/j.pscychresns.2015.01.009

133. Laoutidis ZG, Lekka GE, Kioulos KT. Glutamatergic agents as addon medication for the treatment of obsessive-compulsive disorder: a systematic review and meta-analysis. J Clin Psychiatry. (2016) 77:e157683. doi: 10.4088/JCP.15r10164

134. Bozorgmehr A, Ghadirivasfi M, Shahsavand Ananloo E. Obsessivecompulsive disorder, which genes? Which functions? Which pathways? An integrated holistic view regarding OCD and its complex genetic etiology. $J$ Neurogenet. (2017) 31:153-60. doi: 10.1080/01677063.2017.1336236

135. Rajendram R, Kronenberg S, Burton CL, Arnold PD. Glutamate genetics in obsessive-compulsive disorder: a review. J Can Acad Child Adolesc Psychiatry. (2017) 26:205-13.

136. Mechler K, Hage A, Schweinfurth N, Glennon JC, Dijkhuizen RM, Murphy D, et al. Glutamatergic agents in the treatment of compulsivity and impulsivity in child and adolescent psychiatry: a systematic review of the literature. Z Kinder Jugendpsychiatr Psychother. (2018) 46:24663. doi: 10.1024/1422-4917/a000546

137. Zuchner S, Wendland JR, Ashley-Koch AE, Collins AL, Tran-Viet KN, Quinn K, et al. Multiple rare SAPAP3 missense variants in trichotillomania and OCD. Mol Psychiatry. (2009) 14:6-9. doi: 10.1038/mp.2008.83

138. Song M, Mathews CA, Stewart SE, Shmelkov SV, Mezey JG, RodriguezFlores JL, et al. Rare synaptogenesis-impairing mutations in SLITRK5 are associated with obsessive compulsive disorder. PLoS ONE. (2017) 12:e0169994. doi: 10.1371/journal.pone.0169994

139. Hamouda AK, Wang Z-J, Stewart DS, Jain AD, Glennon RA, Cohen JB. Desformylflustrabromine (dFBr) and [andlt;supandgt;3andlt;/supandgt; $\mathrm{H}$ ]dFBr-Labeled Binding Sites in a Nicotinic Acetylcholine Receptor. Mol Pharmacol. (2015) 88:1. doi: 10.1124/mol.115.098913

140. Greene-Schloesser DM, Van Der Zee EA, Sheppard DK, Castillo MR, Gregg KA, Burrow T, et al. Predictive validity of a non-induced mouse model of compulsive-like behavior. Behav Brain Res. (2011) 221:5562. doi: 10.1016/j.bbr.2011.02.010

141. Mitra S, Bastos CP, Bates K, Pereira GS, Bult-Ito A. Ovarian sex hormones modulate compulsive, affective and cognitive functions in a non-induced mouse model of obsessive-compulsive disorder. Front Behav Neurosci. (2016) 10:215. doi: 10.3389/fnbeh.2016.00215

142. Mitra S, Mucha M, Khatri SN, Glenon R, Schulte MK, Bult-Ito A. Attenuation of compulsive-like behavior through positive allosteric modulation of alpha4beta2 nicotinic acetylcholine receptors in non-induced compulsive-like mice. Front Behav Neurosci. (2016) 10:244. doi: 10.3389/fnbeh.2016.00244

143. Mitra S, Bastos CP, Chesworth S, Frye C, Bult-Ito A. Strain and sex based characterization of behavioral expressions in non-induced compulsive-like mice. Physiol Behav. (2017) 168:103-11. doi: 10.1016/j.physbeh.2016.11.002

144. Mitra S, Mucha M, Owen S, Bult-Ito A. Postpartum lactation-mediated behavioral outcomes and drug responses in a spontaneous mouse model of obsessive-compulsive disorder. ACS Chem Neurosci. (2017) 8:268397. doi: 10.1021/acschemneuro.7b00231
145. Mitra S, Bult-Ito A. Attenuation of compulsive-like behavior by fluvoxamine in a non-induced mouse model of obsessive-compulsive disorder. Behav Pharmacol. (2018) 29:299-305. doi: 10.1097/FBP.0000000000000348

146. Woods A, Smith C, Szewczak M, Dunn RW, Cornfeldt M, Corbett R. Selective serotonin re-uptake inhibitors decrease schedule-induced polydipsia in rats: a potential model for obsessive compulsive disorder. Psychopharmacology (Berl). (1993) 112:195-8. doi: 10.1007/BF02244910

147. Altemus M, Glowa JR, Galliven E, Leong YM, Murphy DL. Effects of serotonergic agents on food-restriction-induced hyperactivity. Pharmacol Biochem Behav. (1996) 53:123-31. doi: 10.1016/0091-3057(95)02003-9

148. Fernández-Guasti A, Agrati D, Reyes R, Ferreira A. Ovarian steroids counteract serotonergic drugs actions in an animal model of obsessive-compulsive disorder. Psychoneuroendocrinology. (2006) 31:924-34. doi: 10.1016/j.psyneuen.2006.05.003

149. Joel D. Current animal models of obsessive compulsive disorder: a critical review. Prog Neuropsychopharmacol Biol Psychiatry. (2006) 30:37488. doi: 10.1016/j.pnpbp.2005.11.006

150. Korff S, Harvey BH. Animal models of obsessive-compulsive disorder: rationale to understanding psychobiology and pharmacology. Psychiatr Clin North Am. (2006) 29:371-90. doi: 10.1016/j.psc.2006.02.007

151. Feusner JD, Hembacher E, Phillips KA. The mouse who couldn't stop washing: pathologic grooming in animals and humans. CNS Spectr. (2009) 14:503-13. doi: 10.1017/S1092852900023567

152. Kalueff AV, Stewart AM, Song C, Berridge KC, Graybiel AM, Fentress JC. Neurobiology of rodent self-grooming and its value for translational neuroscience. Nat Rev Neurosci. (2016) 17:45-59. doi: 10.1038/nrn.2015.8

153. Stein DJ, Shoulberg N, Helton K, Hollander E. The neuroethological approach to obsessive-compulsive disorder. Compr Psychiatry. (1992) 33:274-81. doi: 10.1016/0010-440X(92)90053-S

154. Shumaker AK, Angus JC, Coyner KS, Loeffler DG, Rankin SC, Lewis TP. Microbiological and histopathological features of canine acral lick dermatitis. Vet Dermatol. (2008) 19:288-98. doi: 10.1111/j.1365-3164.2008.00693.x

155. Shumaker AK. Diagnosis and treatment of canine acral lick dermatitis. Vet Clin North Am Small Anim Pract. (2019) 49:105-23. doi: 10.1016/j.cvsm.2018.08.010

156. Protopopova A, Hall NJ, Wynne CD. Association between increased behavioral persistence and stereotypy in the pet dog. Behav Processes. (2014) 106:77-81. doi: 10.1016/j.beproc.2014.04.009

157. Hall NJ. Persistence and resistance to extinction in the domestic dog: basic research and applications to canine training. Behav Processes. (2017) 141:6774. doi: 10.1016/j.beproc.2017.04.001

158. Swanepoel N, Lee E, Stein DJ. Psychogenic alopecia in a cat: response to clomipramine. J S Afr Vet Assoc. (1998) 69:22. doi: 10.4102/jsava.v69i1.804

159. Sawyer LS, Moon-Fanelli AA, Dodman NH. Psychogenic alopecia in cats: 11 cases (1993-1996). J Am Vet Med Assoc. (1999) 214:71-4.

160. Virga V. Behavioral dermatology. Vet Clin North Am Small Anim Pract. (2003) 33:231-51. doi: 10.1016/S0195-5616(02)00102-X

161. Challender DW, Thai NV, Jones M, May L. Time-budgets and activity patterns of captive Sunda pangolins (Manis javanica). Zoo Biol. (2012) 31:206-18. doi: 10.1002/zoo.20381

162. Bennett C, Torgerson-White L, Fripp D, Watters J, Petric A. A Multiinstitutional assessment of factors influencing locomotion and pacing in captive okapis (Okapia johnstoni). J Appl Anim Welf Sci. (2015) 18(Suppl. 1):S43-61. doi: 10.1080/10888705.2015.1075835

163. Khudamrongsawat J, Nakchamnan K, Laithong P, Kongrit C. Abnormal repetitive behaviours of confiscated slow loris (Nycticebus spp.) in Thailand. Folia Primatol (Basel). (2018) 89:216-23. doi: 10.1159/0004 87432

164. Bordnick PS, Thyer BA, Ritchie BW. Feather picking disorder and trichotillomania: an avian model of human psychopathology. J Behav Ther Exp Psychiatry. (1994) 25:189-96. doi: 10.1016/0005-7916(94)90019-1

165. Samson J. Behavioral problems of farmed ostriches in Canada. Can Vet J. (1996) 37:412-4.

166. Jenkins JR. Feather picking and self-mutilation in psittacine birds. Vet Clin North Am Exot Anim Pract. (2001) 4:65167. doi: 10.1016/S1094-9194(17)30029-4

167. Korff S, Stein DJ, Harvey BH. Stereotypic behavior in the deer mouse: pharmacological validation and relevance for obsessive compulsive 
disorder. Prog Neuropsychopharmacol Biol Psychiatry. (2008) 32:34855. doi: 10.1016/j.pnpbp.2007.08.032

168. Wolmarans W, Scheepers IM, Stein DJ, Harvey BH. Peromyscus maniculatus bairdii as a naturalistic mammalian model of obsessive-compulsive disorder: current status and future challenges. Metab Brain Dis. (2018) 33:44355. doi: 10.1007/s11011-017-0161-7

169. Mulder JB. Cribbing in horses: a historical review. Vet Herit. (1993) 16:61-5.

170. Luescher UA, Mckeown DB, Dean H. A cross-sectional study on compulsive behaviour (stable vices) in horses. Equine Vet J Suppl. (1998) 27:148. doi: 10.1111/j.2042-3306.1998.tb05138.x

171. Mcgreevy PD, Nicol CJ. Prevention of crib-biting: a review. Equine Vet $J$ Suppl. (1998) 27:35-8. doi: 10.1111/j.2042-3306.1998.tb05143.x

172. Albright JD, Mohammed HO, Heleski CR, Wickens CL, Houpt KA. Cribbiting in US horses: breed predispositions and owner perceptions of aetiology. Equine Vet J. (2009) 41:455-8. doi: 10.2746/042516409X372584

173. Hothersall B, Nicol C. Role of diet and feeding in normal and stereotypic behaviors in horses. Vet Clin North Am Equine Pract. (2009) 25:16781. doi: 10.1016/j.cveq.2009.01.002

174. Albelda N, Joel D. Animal models of obsessive-compulsive disorder: exploring pharmacology and neural substrates. Neurosci Biobehav Rev. (2012) 36:47-63. doi: 10.1016/j.neubiorev.2011.04.006

175. Albelda N, Joel D. Current animal models of obsessive compulsive disorder: an update. Neuroscience. (2012) 211:83106. doi: 10.1016/j.neuroscience.2011.08.070

176. Joel D, Ben-Amir E, Doljansky J, Flaisher S. 'Compulsive' leverpressing in rats is attenuated by the serotonin re-uptake inhibitors paroxetine and fluvoxamine but not by the tricyclic antidepressant desipramine or the anxiolytic diazepam. Behav Pharmacol. (2004) 15:24152. doi: 10.1097/01.fbp.0000132925.81402.0a

177. Joel D. The signal attenuation rat model of obsessive-compulsive disorder: a review. Psychopharmacology (Berl). (2006) 186:487503. doi: 10.1007/s00213-006-0387-2

178. Welch JM, Lu J, Rodriguiz RM, Trotta NC, Peca J, Ding JD, et al. Corticostriatal synaptic defects and OCD-like behaviours in Sapap3-mutant mice. Nature. (2007) 448:894-900. doi: 10.1038/nature06104

179. Macmaster FP. Translational neuroimaging research in pediatric obsessive-compulsive disorder. Dialogues Clin Neurosci. (2010) 12:165-74. doi: 10.31887/DCNS.2010.12.2/fmacmaster

180. Ting JT, Feng G. Neurobiology of obsessive-compulsive disorder: insights into neural circuitry dysfunction through mouse genetics. Curr Opin Neurobiol. (2011) 21:842-8. doi: 10.1016/j.conb.2011.04.010

181. Lynch CB. Response to divergent selection for nesting behavior in Mus musculus. Genetics. (1980) 96:757-65. doi: 10.1093/genetics/96.3.757

182. Bult A, Lynch CB. Breaking through artificial selection limits of an adaptive behavior in mice and the consequences for correlated responses. Behav Genet. (2000) 30:193-206. doi: 10.1023/A:1001962124005

183. Szechtman H, Sulis W, Eilam D. Quinpirole induces compulsive checking behavior in rats: a potential animal model of obsessivecompulsive disorder (OCD). Behav Neurosci. (1998) 112:147585. doi: $10.1037 / 0735-7044.112 .6 .1475$

184. Szechtman H, Eckert MJ, Tse WS, Boersma JT, Bonura CA, Mcclelland JZ, et al. Compulsive checking behavior of quinpirole-sensitized rats as an animal model of Obsessive-Compulsive Disorder(OCD): form and control. BMC Neurosci. (2001) 2:4. doi: 10.1186/1471-2202-2-4

185. Campos-García Rojas CJ-PF, Flores-Vargas F, Garcia AP. OCD in animal models using quinpirole as dopaminergic inductor of perseverative behaviour. Rev Med Hosp Gen Méx. (2015) 78:169-76. doi: 10.1016/j.hgmx.2015.09.002

186. Tucci MC, Dvorkin-Gheva A, Johnson E, Wong M, Szechtman H. 5-HT2A/C receptors do not mediate the attenuation of compulsive checking by $\mathrm{mCPP}$ in the quinpirole sensitization rat model of obsessive-compulsive disorder (OCD). Behav Brain Res. (2015) 279:211-7. doi: 10.1016/j.bbr.2014.11.017

187. Demeulemeester H, Feys H, Goris I, Zwaenepoel I, De Weerdt W, De Sutter P, et al. Effect of the serotonin agonist 8-OH-DPAT on the sensorimotor system of the rat. Pharmacol Biochem Behav. (2001) 70:95103. doi: 10.1016/S0091-3057(01)00576-7
188. Fernandez-Guasti A, Ulloa RE, Nicolini H. Age differences in the sensitivity to clomipramine in an animal model of obsessive-compulsive disorder. Psychopharmacology (Berl). (2003) 166:195-201. doi: 10.1007/s00213-002-1301-1

189. Van Kuyck K, Demeulemeester H, Feys H, De Weerdt W, Dewil M, Tousseyn $\mathrm{T}$, et al. Effects of electrical stimulation or lesion in nucleus accumbens on the behaviour of rats in a T-maze after administration of 8-OH-DPAT or vehicle. Behav Brain Res. (2003) 140:165-73. doi: 10.1016/S0166-4328(02)00295-4

190. Tsaltas E, Kontis D, Chrysikakou S, Giannou H, Biba A, Pallidi S, et al. Reinforced spatial alternation as an animal model of obsessivecompulsive disorder (OCD): investigation of 5-HT2C and 5-HT1D receptor involvement in OCD pathophysiology. Biol Psychiatry. (2005) 57:117685. doi: 10.1016/j.biopsych.2005.02.020

191. Kreiss DS, Coffman CF, Fiacco NR, Granger JC, Helton BM, Jackson JC, et al. Ritualistic chewing behavior induced by $\mathrm{mCPP}$ in the rat is an animal model of obsessive compulsive disorder. Pharmacol Biochem Behav. (2013) 104:119-24. doi: 10.1016/j.pbb.2013.01.006

192. Zohar J, Mueller EA, Insel TR, Zohar-Kadouch RC, Murphy DL. Serotonergic responsivity in obsessive-compulsive disorder: comparison of patients and healthy controls. Arch Gen Psychiatry. (1987) 44:94651. doi: 10.1001/archpsyc. 1987.01800230026006

193. Zohar J, Insel TR, Zohar-Kadouch RC, Hill JL, Murphy DL. Serotonergic responsivity in obsessive-compulsive disorder. Effects of chronic clomipramine treatment. Arch Gen Psychiatry. (1988) 45:167-72. doi: 10.1001/archpsyc. 1988.01800260081011

194. Shanahan NA, Holick Pierz KA, Masten VL, Waeber C, Ansorge M, Gingrich JA, et al. Chronic reductions in serotonin transporter function prevent 5HT1B-induced behavioral effects in mice. Biol Psychiatry. (2009) 65:4018. doi: 10.1016/j.biopsych.2008.09.026

195. Shanahan NA, Velez LP, Masten VL, Dulawa SC. Essential role for orbitofrontal serotonin $1 \mathrm{~B}$ receptors in obsessive-compulsive disorder-like behavior and serotonin reuptake inhibitor response in mice. Biol Psychiatry. (2011) 70:1039-48. doi: 10.1016/j.biopsych.2011.07.032

196. Ho EV, Thompson SL, Katzka WR, Sharifi MF, Knowles JA, Dulawa SC. Clinically effective OCD treatment prevents 5-HT1B receptor-induced repetitive behavior and striatal activation. Psychopharmacology (Berl). (2016) 233:57-70. doi: 10.1007/s00213-015-4086-8

197. Thompson SL, Dulawa SC. Dissecting the roles of $\beta$-arrestin2 and GSK-3 signaling in 5-HT1BR-mediated perseverative behavior and prepulse inhibition deficits in mice. PLoS ONE. (2019) 14:e0211239. doi: 10.1371/journal.pone.0211239

198. D'Haenen H. Animal models of affective disorders. Neuro Res Comm. (2000) 26:28998. doi: 10.1002/1520-6769(200005/06)26:3<289::AID-NRC15>3.0.CO;2-D

199. Szechtman H, Ahmari SE, Beninger RJ, Eilam D, Harvey BH, Edemann-Callesen $\mathrm{H}$, et al. Obsessive-compulsive disorder: insights from animal models. Neurosci Biobehav Rev. (2017) 76:254-79. doi: 10.1016/j.neubiorev.2016.04.019

200. Fineberg NA, Potenza MN, Chamberlain SR, Berlin HA, Menzies L, Bechara A, et al. Probing compulsive and impulsive behaviors, from animal models to endophenotypes: a narrative review. Neuropsychopharmacology. (2010) 35:591-604. doi: 10.1038/npp.2009.185

201. Zike I, Xu T, Hong N, Veenstra-Vanderweele J. Rodent models of obsessive compulsive disorder: evaluating validity to interpret emerging neurobiology. Neuroscience. (2017) 345:256-73. doi: 10.1016/j.neuroscience.2016.09.012

202. Wang L, Simpson HB, Dulawa SC. Assessing the validity of current mouse genetic models of obsessive-compulsive disorder. Behav Pharmacol. (2009) 20:119-33. doi: 10.1097/FBP.0b013e32832a80ad

203. Ahmari SE. Using mice to model obsessive compulsive disorder: from genes to circuits. Neuroscience. (2016) 321:12137. doi: 10.1016/j.neuroscience.2015.11.009

204. Monteiro P, Feng G. Learning from animal models of obsessive-compulsive disorder. Biol Psychiatry. (2016) 79:7-16. doi: 10.1016/j.biopsych.2015.04.020

205. Zike ID, Chohan MO, Kopelman JM, Krasnow EN, Flicker D, Nautiyal $\mathrm{KM}$, et al. OCD candidate gene SLC1A1/EAAT3 impacts basal gangliamediated activity and stereotypic behavior. Proc Natl Acad Sci USA. (2017) 114:5719-24. doi: 10.1073/pnas.1701736114 
206. Greer JM, Capecchi MR. Hoxb8 is required for normal grooming behavior in mice. Neuron. (2002) 33:23-34. doi: 10.1016/S0896-6273(01)00564-5

207. Burguiere E, Monteiro P, Feng G, Graybiel AM. Optogenetic stimulation of lateral orbitofronto-striatal pathway suppresses compulsive behaviors. Science. (2013) 340:1243-6. doi: 10.1126/science. 1232380

208. Wan Y, Ade KK, Caffall Z, Ilcim Ozlu M, Eroglu C, Feng G, et al. Circuit-selective striatal synaptic dysfunction in the Sapap3 knockout mouse model of obsessive-compulsive disorder. Biol Psychiatry. (2014) 75:62330. doi: 10.1016/j.biopsych.2013.01.008

209. Lei H, Lai J, Sun X, Xu Q, Feng G. Lateral orbitofrontal dysfunction in the Sapap3 knockout mouse model of obsessive-compulsive disorder. $J$ Psychiatry Neurosci. (2018) 44:32. doi: 10.1503/jpn.180032

210. Manning EE, Dombrovski AY, Torregrossa MM, Ahmari SE. Impaired instrumental reversal learning is associated with increased medial prefrontal cortex activity in Sapap3 knockout mouse model of compulsive behavior. Neuropsychopharmacology. (2019) 44:1494-504. doi: 10.1038/s41386-018-0307-2

211. Pinhal CM, Van Den Boom BJG, Santana-Kragelund F, Fellinger L, Bech P, Hamelink R, et al. Differential effects of deep brain stimulation of the internal capsule and the striatum on excessive grooming in Sapap3 mutant mice. Biol Psychiatry. (2018) 84:917-25. doi: 10.1016/j.biopsych.2018.05.011

212. Boardman L, Van Der Merwe L, Lochner C, Kinnear CJ, Seedat S, Stein DJ, et al. Investigating SAPAP3 variants in the etiology of obsessive-compulsive disorder and trichotillomania in the South African white population. Compr Psychiatry. (2011) 52:181-7. doi: 10.1016/j.comppsych.2010.05.007

213. Bienvenu OJ, Wang Y, Shugart YY, Welch JM, Grados MA, Fyer AJ, et al. Sapap3 and pathological grooming in humans: results from the OCD collaborative genetics study. Am J Med Genet B Neuropsychiatr Genet. (2009) 150b:710-20. doi: 10.1002/ajmg.b.30897

214. Heisler LK, Tecott LH. Knockout corner: neurobehavioural consequences of a serotonin 5-HT(2C) receptor gene mutation. Int J Neuropsychopharmacol. (1999) 2:67-9. doi: 10.1017/S1461145799001327

215. Tecott LH, Logue SF, Wehner JM, Kauer JA. Perturbed dentate gyrus function in serotonin 5-HT2C receptor mutant mice. Proc Natl Acad Sci USA. (1998) 95:15026-31. doi: 10.1073/pnas.95.25.15026

216. Shmelkov SV, Hormigo A, Jing D, Proenca CC, Bath KG, Milde T, et al. Slitrk5 deficiency impairs corticostriatal circuitry and leads to obsessive-compulsive-like behaviors in mice. Nat Med. (2010) 16:598602. doi: $10.1038 / \mathrm{nm} .2125$

217. Delgado-Acevedo C, Estay SF, Radke A, Sengupta A, Escobar AP, Henriquez-Belmar F, et al. Behavioral and synaptic alterations relevant to obsessive-compulsive disorder in mice with increased EAAT3 expression. Neuropsychopharmacology. (2019) 44:116373. doi: $10.1038 / \mathrm{s} 41386-018-0302-7$

218. Wendland JR, Moya PR, Timpano KR, Anavitarte AP, Kruse MR, Wheaton MG, et al. A haplotype containing quantitative trait loci for SLC1A1 gene expression and its association with obsessive-compulsive disorder. Arch Gen Psychiatry. (2009) 66:408-16. doi: 10.1001/archgenpsychiatry.2009.6

219. Van Der Staay FJ, Arndt SS, Nordquist RE. Evaluation of animal models of neurobehavioral disorders. Behav Brain Funct. (2009) 5:11. doi: 10.1186/1744-9081-5-11

220. Baker M. Animal models: inside the minds of mice and men. Nature. (2011) 475:123-8. doi: 10.1038/475123a

221. Belzung C, Lemoine M. Criteria of validity for animal models of psychiatric disorders: focus on anxiety disorders and depression. Biol Mood Anxiety Disord. (2011) 1:9. doi: 10.1186/2045-5380-1-9

222. Wolmarans De W, Stein DJ, Harvey BH. Of mice and marbles: novel perspectives on burying behavior as a screening test for psychiatric illness. Cogn Affect Behav Neurosci. (2016) 16:551-60. doi: 10.3758/s13415-016-0413-8

223. Alonso $\mathrm{P}$, López-Solà $\mathrm{C}$, Real $\mathrm{E}$, Segalàs $\mathrm{C}$, Menchón JM. Animal models of obsessive-compulsive disorder: utility and limitations. Neuropsychiatr Dis Treat. (2015) 11:1939-55. doi: 10.2147/NDT.S62785

224. Kotapati VP, Khan AM, Dar S, Begum G, Bachu R, Adnan M, et al. The effectiveness of selective serotonin reuptake inhibitors for treatment of obsessive-compulsive disorder in adolescents and children: a systematic review and meta-analysis. Front Psychiatry. (2019) 10:523. doi: $10.3389 /$ fpsyt.2019.00523
225. Tatsumi M, Groshan K, Blakely RD, Richelson E. Pharmacological profile of antidepressants and related compounds at human monoamine transporters. Eur J Pharmacol. (1997) 340:249-58. doi: 10.1016/S0014-2999(97)01393-9

226. Eshleman AJ, Carmolli M, Cumbay M, Martens CR, Neve KA, Janowsky A. Characteristics of drug interactions with recombinant biogenic amine transporters expressed in the same cell type. J Pharmacol Exp Ther. (1999) 289:877-85.

227. Brock H, Hany M. Obsessive-Compulsive Disorder. Treasure Island, FL: StatPearls Publishing (2021). Available online at: https://www.ncbi.nlm.nih. gov/books/NBK553162/ (accessed December 8, 2020).

228. Chamberlain SR, Blackwell AD, Fineberg NA, Robbins TW, Sahakian BJ. The neuropsychology of obsessive compulsive disorder: the importance of failures in cognitive and behavioural inhibition as candidate endophenotypic markers. Neurosci Biobehav Rev. (2005) 29:399-419. doi: 10.1016/j.neubiorev.2004.11.006

229. Menzies L, Chamberlain SR, Laird AR, Thelen SM, Sahakian BJ, Bullmore ET. Integrating evidence from neuroimaging and neuropsychological studies of obsessive-compulsive disorder: the orbitofronto-striatal model revisited. Neurosci Biobehav Rev. (2008) 32:525-49. doi: 10.1016/j.neubiorev.2007.09.005

230. Bult A, Lynch CB. Multiple selection responses in house mice bidirectionally selected for thermoregulatory nest-building behavior: crosses of replicate lines. Behav Genet. (1996) 26:439-46. doi: 10.1007/BF02359488

231. Mcclearn GE, Wilson JR, Meredith W. The use of isogenic and heterogenic mouse stocks in behavioral research. In: Lindzey G, Thiessen DD, editors. Contrib To Behavior-Genetic. New York, NY: Appleton-Century-Crofts, (1970). p. 3-22.

232. Wallace ME. The breeding inbreeding and management of wild mice. Symp Zool Soc London. (1981) 47:183-204.

233. Lynch C. B. Clinical variation in cold adaptation in Mus domesticus: verification of predictions from laboratory populations. Am Nat. (1994) 139:1219-36. doi: 10.1086/285383

234. Bult A, Lynch CB. Nesting and fitness: lifetime reproductive success in house mice bidirectionally selected for thermoregulatory nest-building behavior. Behav Genet. (1997) 27:231-40. doi: 10.1023/A:1025610130282

235. Gaskill BN, Gordon CJ, Pajor EA, Lucas JR, Davis JK, Garner JP. Heat or insulation: behavioral titration of mouse preference for warmth or access to a nest. PLoS ONE. (2012) 7:e32799. doi: 10.1371/journal.pone.0032799

236. Boake CRB. Quantitative Genetic Studies of Behavioral Evolution. Chicago: University of Chicago Press (1994).

237. Neely CLC, Pedemonte KA, Boggs KN, Flinn JM. Nest building behavior as an early indicator of behavioral deficits in mice. J Vis Exp. (2019) 152. doi: $10.3791 / 60139$

238. Collias NE. The evolution of nests and nest-building in birds. Am Zool. (1964) 4:175-90. doi: 10.1093/icb/4.2.175

239. Mainwaring MC, Hartley IR, Lambrechts MM, Deeming DC. The design and function of birds' nests. Ecol Evol. (2014) 4:3909-28. doi: 10.1002/ece3.1054

240. Lewarch CL, Hoekstra HE. The evolution of nesting behaviour in Peromyscus mice. Anim Behav. (2018) 139:10315. doi: 10.1016/j.anbehav.2018.03.008

241. Szechtman H, Woody EZ. Obsessive-compulsive disorder as a disturbance of security motivation: constraints on comorbidity. Neurotox Res. (2006) 10:103-12. doi: 10.1007/BF03033239

242. Szechtman H, Harvey BH, Woody EZ, Hoffman KL. The psychopharmacology of obsessive-compulsive disorder: a preclinical roadmap. Pharmacol Rev. (2020) 72:80-151. doi: 10.1124/pr.119.017772

243. Potenza MN, Koran LM, Pallanti S. The relationship between impulsecontrol disorders and obsessive-compulsive disorder: a current understanding and future research directions. Psychiatry Res. (2009) 170:22-31. doi: 10.1016/j.psychres.2008.06.036

244. Grant JE, Mancebo MC, Eisen JL, Rasmussen SA. Impulse-control disorders in children and adolescents with obsessive-compulsive disorder. Psychiatry Res. (2010) 175:109-13. doi: 10.1016/j.psychres.2009. 04.006

245. Grassi G, Pallanti S, Righi L, Figee M, Mantione M, Denys D, et al. Think twice: impulsivity and decision making in obsessivecompulsive disorder. J Behav Addict. (2015) 4:263-72. doi: 10.1556/2006.4. 2015.039 
246. Deacon RM, Croucher A, Rawlins JN. Hippocampal cytotoxic lesion effects on species-typical behaviours in mice. Behav Brain Res. (2002) 132:20313. doi: 10.1016/S0166-4328(01)00401-6

247. Deacon RMJ, Penny C, Rawlins JNP. Effects of medial prefrontal cortex cytotoxic lesions in mice. Behav Brain Res. (2003) 139:13955. doi: 10.1016/S0166-4328(02)00225-5

248. Jedynak P, Jaholkowski P, Wozniak G, Sandi C, Kaczmarek L, Filipkowski RK. Lack of cyclin D2 impairing adult brain neurogenesis alters hippocampaldependent behavioral tasks without reducing learning ability. Behav Brain Res. (2012) 227:159-66. doi: 10.1016/j.bbr.2011.11.007

249. Kondratiuk I, Devijver H, Lechat B, Van Leuven F, Kaczmarek L, Filipkowski RK. Glycogen synthase kinase-3beta affects size of dentate gyrus and speciestypical behavioral tasks in transgenic and knockout mice. Behav Brain Res. (2013) 248:46-50. doi: 10.1016/j.bbr.2013.03.045

250. Corder KM, Cortes MA, Bartley AF, Lear SA, Lubin FD, Dobrunz LE. Prefrontal cortex-dependent innate behaviors are altered by selective knockdown of Gad1 in neuropeptide Y interneurons. PLoS ONE. (2018) 13:e0200809. doi: 10.1371/journal.pone.0200809

251. Lerch-Haner JK, Frierson D, Crawford LK, Beck SG, Deneris ES. Serotonergic transcriptional programming determines maternal behavior and offspring survival. Nat Neurosci. (2008) 11:1001-3. doi: 10.1038/nn.2176

252. Hall ZJ, Meddle SL, Healy SD. From neurons to nests: nest-building behaviour as a model in behavioural and comparative neuroscience. $J$ Ornithol. (2015) 156:133-43. doi: 10.1007/s10336-015-1214-5

253. Ahmari SE, Risbrough VB, Geyer MA, Simpson HB. Impaired sensorimotor gating in unmedicated adults with obsessive-compulsive disorder. Neuropsychopharmacology. (2012) 37:1216-23. doi: 10.1038/npp.2011.308

254. Pittenger C, Adams TG, Jr., Gallezot J-D, Crowley MJ, Nabulsi N, James R, et al. OCD is associated with an altered association between sensorimotor gating and cortical and subcortical 5-HT1b receptor binding. J Affect Disord. (2016) 196:87-96. doi: 10.1016/j.jad.2016.02.021

255. Takeda T, Sumitani S, Hamatani S, Yokose Y, Shikata M, Ohmori T. Prefrontal cortex activation during neuropsychological tasks might predict response to pharmacotherapy in patients with obsessive-compulsive disorder. Neuropsychiatr Dis Treat. (2017) 13:577-83. doi: 10.2147/NDT.S127752

256. Rao S, Raveendranathan D, Shivakumar V, Narayanaswamy JC, Venkatasubramanian G, Reddy YCJ. Hippocampus volume alterations and the clinical correlates in medication naïve obsessive compulsive disorder. J Affect Disord. (2018) 236:1-5. doi: 10.1016/j.jad.2018.04.048

257. Gurok MG, Korucu T, Kilic MC, Yildirim H, Atmaca M. Hippocampus and amygdalar volumes in patients with obsessive-compulsive personality disorder. J Clin Neurosci. (2019) 64:259-63. doi: 10.1016/j.jocn.2019. 03.060

258. Liao J, Li T, Dong W, Wang J, Tian J, Liu J, et al. Reduced prefrontal-temporal cortical activation during verbal fluency task in obsessive-compulsive disorder: a multi-channel near-infrared spectroscopy study. J Psychiatr Res. (2019) 109:33-40. doi: 10.1016/j.jpsychires.2018.11.006

259. Simmler LD, Ozawa T. Neural circuits in goal-directed and habitual behavior: implications for circuit dysfunction in obsessive-compulsive disorder. Neurochem Int. (2019) 129:104464. doi: 10.1016/j.neuint.2019.104464

260. Deacon RM, Rawlins JN. Hippocampal lesions, species-typical behaviours and anxiety in mice. Behav Brain Res. (2005) 156:241-9. doi: 10.1016/j.bbr.2004.05.027

261. Smithers RHN. Families CRICETIDAE and MURIDAE, rats and mice. In: The Mammals of the Southern-African Subregion Pretoria, South Africa. Pretoria: University of Pretoria (1983).

262. Uday G, Pravinkumar B, Manish W, Sudhir U. LHRH antagonist attenuates the effect of fluoxetine on marble-burying behavior in mice. Eur J Pharmacol. (2007) 563:155-9. doi: 10.1016/j.ejphar.2007.02.016

263. Umathe SN, Vaghasiya JM, Jain NS, Dixit P. Neurosteroids modulate compulsive and persistent behavior in rodents: implications for obsessivecompulsive disorder. Prog Neuropsychopharmacol Biol Psychiatry. (2009) 33:1161-6. doi: 10.1016/j.pnpbp.2009.06.013

264. Taylor GT, Lerch S, Chourbaji S. Marble burying as compulsive behaviors in male and female mice. Acta Neurobiol Exp (Wars). (2017) 77:25460. doi: 10.21307/ane-2017-059
265. Egashira N, Kubota N, Goto Y, Watanabe T, Kubota K, Katsurabayashi $\mathrm{S}$, et al. The antipsychotic trifluoperazine reduces marble-burying behavior in mice via $\mathrm{D}(2)$ and $5-\mathrm{HT}(2 \mathrm{~A})$ receptors: implications for obsessive-compulsive disorder. Pharmacol Biochem Behav. (2018) 165:9-13. doi: 10.1016/j.pbb.2017.12.006

266. Njung'e K, Handley SL. Evaluation of marble-burying behavior as a model of anxiety. Pharmacol Biochem Behav. (1991) 38:63-7. doi: 10.1016/0091-3057(91)90590-X

267. Gyertyán I. Analysis of the marble burying response: marbles serve to measure digging rather than evoke burying. Behav Pharmacol. (1995) 6:2431. doi: 10.1097/00008877-199501000-00005

268. Londei T, Valentini AM, Leone VG. Investigative burying by laboratory mice may involve non-functional, compulsive, behaviour. Behav Brain Res. (1998) 94:249-54. doi: 10.1016/S0166-4328(97)00162-9

269. Teissier A, Le Magueresse C, Olusakin J, Andrade Da Costa BLS, De Stasi $\mathrm{AM}$, Bacci A, et al. Early-life stress impairs postnatal oligodendrogenesis and adult emotional behaviour through activity-dependent mechanisms. Mol Psychiatry. (2020) 25:1159-74. doi: 10.1038/s41380-019-0493-2

270. Thomas A, Burant A, Bui N, Graham D, Yuva-Paylor LA, Paylor R. Marble burying reflects a repetitive and perseverative behavior more than novelty-induced anxiety. Psychopharmacology. (2009) 204:36173. doi: 10.1007/s00213-009-1466-y

271. Dietrich MO, Zimmer MR, Bober J, Horvath TL. Hypothalamic agrp neurons drive stereotypic behaviors beyond feeding. Cell. (2015) 160:122232. doi: 10.1016/j.cell.2015.02.024

272. Egashira N, Okuno R, Harada S, Matsushita M, Mishima K, Iwasaki K, et al. Effects of glutamate-related drugs on marble-burying behavior in mice: Implications for obsessive-compulsive disorder. Eur J Pharmacol. (2008) 586:164-70. doi: 10.1016/j.ejphar.2008.01.035

273. Gomes FV, Casarotto PC, Resstel LB, Guimarães FS. Facilitation of CB1 receptor-mediated neurotransmission decreases marble burying behavior in mice. Prog Neuropsychopharmacol Biol Psychiatry. (2011) 35:4348. doi: 10.1016/j.pnpbp.2010.11.027

274. Hoffman KL. Animal models of obsessive compulsive disorder: recent findings and future directions. Expert Opin Drug Discov. (2011) 6:72537. doi: 10.1517/17460441.2011.577772

275. Schüle C, Eser D, Baghai TC, Nothdurfter C, Kessler JS, Rupprecht R. Neuroactive steroids in affective disorders: target for novel antidepressant or anxiolytic drugs? Neuroscience. (2011) 191:55-77. doi: 10.1016/j.neuroscience.2011.03.025

276. Lustberg D, Iannitelli AF, Tillage RP, Pruitt M, Liles LC, Weinshenker D. Central norepinephrine transmission is required for stress-induced repetitive behavior in two rodent models of obsessive-compulsive disorder. Psychopharmacology (Berl). (2020) 237:1973-87. doi: 10.1007/s00213-020-05512-0

277. Jury NJ, Mccormick BA, Horseman ND, Benoit SC, Gregerson KA. Enhanced responsiveness to selective serotonin reuptake inhibitors during lactation. PLoS ONE. (2015) 10:e0117339. doi: 10.1371/journal.pone.0117339

278. Kant R, Pasi S, Surolia A. Auto-reactive Th17-cells trigger obsessive-compulsive-disorder like behavior in mice with experimental autoimmune encephalomyelitis. Front Immunol. (2018) 9:2508. doi: 10.3389/fimmu.2018.02508

279. Mitra S, Santana Miranda V, Mcmillan C, Dykes D, Mucha M, Marth TE, et al. Trait specific modulatory effects of caffeine exposure on compulsive-like behaviors in a spontaneous mouse model of obsessive-compulsive disorder. Behav Pharmacol. (2020) 31:622-32. doi: 10.1097/FBP.0000000000000570

280. Parks CL, Robinson PS, Sibille E, Shenk T, Toth M. Increased anxiety of mice lacking the serotonin1A receptor. Proc Natl Acad Sci USA. (1998) 95:10734-9. doi: 10.1073/pnas.95.18.10734

281. Belzung C, Griebel G. Measuring normal and pathological anxietylike behaviour in mice: a review. Behav Brain Res. (2001) 125:1419. doi: 10.1016/S0166-4328(01)00291-1

282. Pauls DL, Alsobrook JP, II, Goodman W, Rasmussen S, Leckman JF. A family study of obsessive-compulsive disorder. Am J Psychiatry. (1995) 152:76-84. doi: 10.1176/ajp.152.1.76

283. Nestadt G, Samuels J, Riddle M, Bienvenu OJ, III, Liang KY, Labuda M, Walkup J, et al. A family study of obsessive-compulsive disorder. Arch Gen Psychiatry. (2000) 57:358-63. doi: 10.1001/archpsyc.57.4.358 
284. Lipsitz JD, Mannuzza S, Chapman TF, Foa EB, Franklin ME, Goodwin $\mathrm{RD}$, et al. A direct interview family study of obsessive-compulsive disorder. II Contribution of proband informant information. Psychol Med. (2005) 35:1623-31. doi: 10.1017/S003329170500543X

285. Grabe HJ, Ruhrmann S, Ettelt S, Buhtz F, Hochrein A, SchulzeRauschenbach S, et al. Familiality of obsessive-compulsive disorder in nonclinical and clinical subjects. Am J Psychiatry. (2006) 163:198692. doi: 10.1176/ajp.2006.163.11.1986

286. Black DW, Stumpf A, Mccormick B, Allen J, Blum N, Noyes R. A blind re-analysis of the Iowa family study of obsessive-compulsive disorder. Psychiatry Res. (2013) 209:202-6. doi: 10.1016/j.psychres.2013.04.013

287. Taylor S. Etiology of obsessions and compulsions: a meta-analysis and narrative review of twin studies. Clin Psychol Rev. (2011) 31:136172. doi: $10.1016 /$ j.cpr.2011.09.008

288. Schweitzer B, Suter U, Taylor V. Neural membrane protein 35/Lifeguard is localized at postsynaptic sites and in dendrites. Brain Res Mol Brain Res. (2002) 107:47-56. doi: 10.1016/S0169-328X(02)00445-X

289. Perez-Torrado R, Yamada D, Defossez PA. Born to bind: the BTB protein-protein interaction domain. Bioessays. (2006) 28:1194-202. doi: 10.1002/bies.20500

290. Wieczorek L, Maas JW, Jr., Muglia LM, Vogt SK, Muglia LJ. Temporal and regional regulation of gene expression by calcium-stimulated adenylyl cyclase activity during fear memory. PLoS ONE. (2010) 5:e13385. doi: 10.1371/journal.pone.0013385

291. Cappi C, Oliphant ME, Péter Z, Zai G, Conceição Do Rosário $\mathrm{M}$, Sullivan $\mathrm{C}$, et al. De novo damaging DNA coding mutations are associated with obsessive-compulsive disorder and overlap with tourette's disorder and autism. Biol Psychiatry. (2020) 87:1035-44. doi: 10.1016/j.biopsych.2019.09.029

292. Bogetto F, Venturello S, Albert U, Maina G, Ravizza L. Gender-related clinical differences in obsessive-compulsive disorder. Eur Psychiatry. (1999) 14:434-41. doi: 10.1016/S0924-9338(99)00224-2

293. Brandes M, Soares CN, Cohen LS. Postpartum onset obsessive-compulsive disorder: diagnosis and management. Arch Womens Ment Health. (2004) 7:99-110. doi: 10.1007/s00737-003-0035-3

294. Brook CG. Mechanism of puberty. Horm Res. (1999) 51(Suppl. 3):524. doi: $10.1159 / 000053162$

295. Barth C, Villringer A, Sacher J. Sex hormones affect neurotransmitters and shape the adult female brain during hormonal transition periods. Front Neurosci. (2015) 9:37-37. doi: 10.3389/fnins.2015.00037

296. Dreher J-C, Schmidt PJ, Kohn P, Furman D, Rubinow D, Berman KF. Menstrual cycle phase modulates reward-related neural function in women. Proc Natl Acad Sci USA. (2007) 104:2465-70. doi: 10.1073/pnas.0605569104

297. Karakaya S, Kipp M, Beyer C. Oestrogen regulates the expression and function of dopamine transporters in astrocytes of the nigrostriatal system. J Neuroendocrinol. (2007) 19:682-90. doi: 10.1111/j.1365-2826.2007.01575.x

298. Benmansour S, Piotrowski JP, Altamirano AV, Frazer A. Impact of ovarian hormones on the modulation of the serotonin transporter by fluvoxamine. Neuropsychopharmacology. (2009) 34:555-64. doi: 10.1038/npp.2008.23

299. Kokate TG, Svensson BE, Rogawski MA. Anticonvulsant activity of neurosteroids: correlation with gamma-aminobutyric acid-evoked chloride current potentiation. J Pharmacol Exp Ther. (1994) 270:1223-9.

300. Khisti RT, Chopde CT, Jain SP. Antidepressant-like effect of the neurosteroid 3alpha-hydroxy-5alpha-pregnan-20-one in mice forced swim test. Pharmacol Biochem Behav. (2000) 67:137-43. doi: 10.1016/S0091-3057(00)00300-2

301. Barbaccia ML. Neurosteroidogenesis: relevance to neurosteroid actions in brain and modulation by psychotropic drugs. Crit Rev Neurobiol. (2004) 16:67-74. doi: 10.1615/CritRevNeurobiol.v16.i12.70

302. Compagnone NA, Mellon SH. Neurosteroids: biosynthesis and function of these novel neuromodulators. Front Neuroendocrinol. (2000) 21:156. doi: $10.1006 /$ frne.1999.0188

303. Alcafache J. Sex hormones fluctuation and obsessive compulsive disorder. $J$ Neurol Psychol. (2016) 4:24. doi: 10.13188/2332-3469.1000024

304. Sauce B, De Brito RA, Peripato AC. Genetic architecture of nest building in mice LG/J × SM/J. Front Genet. (2012) 3:90. doi: 10.3389/fgene.2012.00090

305. Bendesky A, Kwon Y-M, Lassance J-M, Lewarch CL, Yao S, Peterson BK, et al. The genetic basis of parental care evolution in monogamous mice. Nature. (2017) 544:434-9. doi: 10.1038/nature 22074

306. Anholt RRH, O'grady P, Wolfner MF, Harbison ST. Evolution of reproductive behavior. Genetics. (2020) 214:49. doi: 10.1534/genetics.119.302263

307. Goodman WK, Price LH, Delgado PL, Palumbo J, Krystal JH, Nagy LM, et al. Specificity of serotonin reuptake inhibitors in the treatment of obsessive-compulsive disorder. Comparison of fluvoxamine and desipramine. Arch Gen Psychiatry. (1990) 47:577-85. doi: 10.1001/archpsyc. 1990.01810180077011

308. Greist JH. The comparative effectiveness of treatments for obsessivecompulsive disorder. Bull Menninger Clin. (1998) 62:A65-81.

309. Hoehn-Saric R, Ninan P, Black DW, Stahl S, Greist JH, Lydiard B, et al. Multicenter double-blind comparison of sertraline and desipramine for concurrent obsessive-compulsive and major depressive disorders. Arch Gen Psychiatry. (2000) 57:76-82. doi: 10.1001/archpsyc.57.1.76

310. Micallef J, Blin O. Neurobiology and clinical pharmacology of obsessive-compulsive disorder. Clin Neuropharmacol. (2001) 24:191-207. doi: 10.1097/00002826-200107000-00002

311. Brakoulias V. Managing obsessive compulsive disorder. Aust Prescr. (2015) 38:121-3. doi: 10.18773 /austprescr.2015.040

312. March JS, Franklin ME, Leonard H, Garcia A, Moore P, Freeman J, et al. Tics moderate treatment outcome with sertraline but not cognitive-behavior therapy in pediatric obsessive-compulsive disorder. Biol Psychiatry. (2007) 61:344-7. doi: 10.1016/j.biopsych.2006.09.035

313. Lack CW. Obsessive-compulsive disorder: evidence-based treatments and future directions for research. World J Psychiatry. (2012) 2:8690. doi: 10.5498/wjp.v2.i6.86

314. Koran L, Hanna G, Hollander E, Nestadt G, Simpson H. Practice guideline for the treatment of patients with obsessive-compulsive disorder. Am J Psychiatry. (2007) 164:5-53.

315. Vulink NC, Denys D, Bus L, Westenberg HG. Female hormones affect symptom severity in obsessive-compulsive disorder. Int Clin Psychopharmacol. (2006) 21:171-5. doi: 10.1097/01.yic.0000199454.62423.99

316. Uguz F, Sahingoz M, Gezginc K, Karatayli R. Obsessive-compulsive disorder in postmenopausal women: prevalence, clinical features, and comorbidity. Aust N Z J Psychiatry. (2010) 44:183-7. doi: 10.3109/00048670903 393639

317. Guglielmi V, Vulink NC, Denys D, Wang Y, Samuels JF, Nestadt G. Obsessive-compulsive disorder and female reproductive cycle events: results from the OCD and reproduction collaborative study. Depress Anxiety. (2014) 31:979-87. doi: 10.1002/da.22234

318. Rodríguez-Landa JF, Puga-Olguín A, Germán-Ponciano LJ, GarcíaRíos R-I, Soria-Fregozo C. Anxiety in natural and surgical menopause-physiologic and therapeutic bases. In: Durbano F, editor. A Fresh Look at Anxiety Disorders. Rijeka: InTech (2015). p. 173-98. doi: 10.5772/60621

319. Hill RA, Mcinnes KJ, Gong EC, Jones ME, Simpson ER, Boon WC. Estrogen deficient male mice develop compulsive behavior. Biol Psychiatry. (2007) 61:359-66. doi: 10.1016/j.biopsych.2006.01.012

320. Flaisher-Grinberg S, Albelda N, Gitter L, Weltman K, Arad M, Joel D. Ovarian hormones modulate 'compulsive' lever-pressing in female rats. Horm Behav. (2009) 55:356-65. doi: 10.1016/j.yhbeh.2008.10.002

321. Fontenelle LF, Mendlowicz MV, Versiani M. Clinical subtypes of obsessive-compulsive disorder based on the presence of checking and washing compulsions. Braz J Psychiatry. (2005) 27:201-7. doi: 10.1590/S1516-44462005000300008

322. Grados M, Riddle MA. Do all obsessive-compulsive disorder subtypes respond to medication? Int Rev Psychiatry. (2008) 20:189-93. doi: 10.1080/09540260801889153

323. Leckman JF, Bloch MH, King RA. Symptom dimensions and subtypes of obsessive-compulsive disorder: a developmental perspective. Dialogues Clin Neurosci. (2009) 11:21-33. doi: 10.31887/DCNS.2009.11.1/jfleckman

324. Abramowitz JS, Schwartz SA, Moore KM. Obsessional thoughts in postpartum females and their partners: content, severity, and relationship with depression. J Clin Psychol Med Settings. (2003) 10:157-64. doi: 10.1023/A:1025454627242

325. Doornbos B, Fekkes D, Tanke MAC, De Jonge P, Korf J. Sequential serotonin and noradrenalin associated processes involved in postpartum 
blues. Prog Neuro Psychopharmacol Biol Psychiatry. (2008) 32:13205. doi: 10.1016/j.pnpbp.2008.04.010

326. Caldwell JD, Greer ER, Johnson MF, Prange AJJr, Pedersen CA. Oxytocin and vasopressin immunoreactivity in hypothalamic and extrahypothalamic sites in late pregnant and postpartum rats. Neuroendocrinology. (1987) 46:39-47. doi: 10.1159/000124794

327. Zingg HH, Lefebvre DL. Oxytocin and vasopressin gene expression during gestation and lactation. Brain Res. (1988) 464:1-6. doi: 10.1016/0169-328X(88)90011-3

328. Mezey E, Kiss JZ. Coexpression of vasopressin and oxytocin in hypothalamic supraoptic neurons of lactating rats. Endocrinology. (1991) 129:181420. doi: 10.1210/endo-129-4-1814

329. Cochran DM, Fallon D, Hill M, Frazier JA. The role of oxytocin in psychiatric disorders: a review of biological and therapeutic research findings. Harv Rev Psychiatry. (2013) 21:219-47. doi: 10.1097/HRP.0b013e3182a75b7d

330. Neumann ID, Slattery DA. Oxytocin in general anxiety and social fear: a translational approach. Biol Psychiatry. (2016) 79:213-21. doi: 10.1016/j.biopsych.2015.06.004

331. Miller ES, Chu C, Gollan J, Gossett DR. Obsessive-compulsive symptoms during the postpartum period. A prospective cohort. I Reprod Med. (2013) 58:115-22.

332. Lucey JV, Butcher G, Clare AW, Dinan TG. Elevated growth hormone responses to pyridostigmine in obsessive-compulsive disorder: evidence of cholinergic supersensitivity. Am J Psychiatry. (1993) 150:961-2. doi: 10.1176/ajp.150.6.961

333. Yankelevitch-Yahav R, Joel D. The role of the cholinergic system in the signal attenuation rat model of obsessivecompulsive disorder. Psychopharmacology (Berl). (2013) 230:3748. doi: 10.1007/s00213-013-3323-2

334. Abramovitch A, Pizzagalli DA, Geller DA, Reuman L, Wilhelm S. Cigarette smoking in obsessive-compulsive disorder and unaffected parents of OCD patients. Eur Psychiatry. (2015) 30:137-44. doi: 10.1016/j.eurpsy.2013.12.003

335. Pasquini M, Garavini A, Biondi M. Nicotine augmentation for refractory obsessive-compulsive disorder. A case report. Prog Neuro Psychopharmacol Biol Psychiatry. (2005) 29:157-9. doi: 10.1016/j.pnpbp.2004.08.011

336. Mesulam MM, Volicer L, Marquis JK, Mufson EJ, Green RC. Systematic regional differences in the cholinergic innervation of the primate cerebral cortex: distribution of enzyme activities and some behavioral implications. Ann Neurol. (1986) 19:144-51. doi: 10.1002/ana.410190206

337. Beucke JC, Sepulcre J, Talukdar T, Linnman C, Zschenderlein K, Endrass $\mathrm{T}$, et al. Abnormally high degree connectivity of the orbitofrontal cortex in obsessive-compulsive disorder. JAMA Psychiatry. (2013) 70:61929. doi: 10.1001 /jamapsychiatry.2013.173

338. Martos YV, Braz BY, Beccaria JP, Murer MG, Belforte JE. Compulsive social behavior emerges after selective ablation of striatal cholinergic interneurons. J Neurosci. (2017) 37:2849-58. doi: 10.1523/JNEUROSCI.3460-16.2017

339. Claghorn GC, Thompson Z, Wi K, Van L, Garland TJr. Caffeine stimulates voluntary wheel running in mice without increasing aerobic capacity. Physiol Behav. (2017) 170:133-40. doi: 10.1016/j.physbeh.2016.12.031

340. Fredholm BB, Bättig K, Holmén J, Nehlig A, Zvartau EE. Actions of caffeine in the brain with special reference to factors that contribute to its widespread use. Pharmacol Rev. (1999) 51:83-133.

341. Smith A. Effects of caffeine on human behavior. Food Chem Toxicol. (2002) 40:1243-55. doi: 10.1016/S0278-6915(02)00096-0

342. Masi G, Perugi G, Millepiedi S, Toni C, Mucci M, Pfanner C, et al. Bipolar co-morbidity in pediatric obsessive-compulsive disorder: clinical and treatment implications. J Child Adolesc Psychopharmacol. (2007) 17:475-86. doi: 10.1089/cap.2006.0107

343. Perugi G, Toni C, Frare F, Travierso MC, Hantouche E, Akiskal HS. Obsessive-compulsive-bipolar comorbidity: a systematic exploration of clinical features and treatment outcome. J Clin Psychiatry. (2002) 63:112934. doi: 10.4088/JCP.v63n1207

344. Okuro M, Fujiki N, Kotorii N, Ishimaru Y, Sokoloff P, Nishino S. Effects of paraxanthine and caffeine on sleep, locomotor activity, and body temperature in orexin/ataxin-3 transgenic narcoleptic mice. Sleep. (2010) 33:930-42. doi: 10.1093/sleep/33.7.930

345. Mao J-H, Langley SA, Huang Y, Hang M, Bouchard KE, Celniker SE, et al. Identification of genetic factors that modify motor performance and body weight using collaborative cross mice. Sci Rep. (2015) 5:16247. doi: $10.1038 /$ srep 16247

346. Lochner C, Stein DJ. Heterogeneity of obsessive-compulsive disorder: a literature review. Harv Rev Psychiatry. (2003) 11:113-32. doi: 10.1080/10673220303949

347. Malkova NV, Yu CZ, Hsiao EY, Moore MJ, Patterson PH. Maternal immune activation yields offspring displaying mouse versions of the three core symptoms of autism. Brain Behav Immun. (2012) 26:60716. doi: 10.1016/j.bbi.2012.01.011

348. Schwartzer JJ, Careaga M, Onore CE, Rushakoff JA, Berman RF, Ashwood P. Maternal immune activation and strain specific interactions in the development of autism-like behaviors in mice. Transl Psychiatry. (2013) 3:e240. doi: $10.1038 /$ tp.2013.16

349. Xuan ICY, Hampson DR. Gender-dependent effects of maternal immune activation on the behavior of mouse offspring. PLoS ONE. (2014) 9:e104433. doi: 10.1371/journal.pone. 0104433

350. Radhakrishnan R, Kaser M, Guloksuz S. The link between the immune system, environment, and psychosis. Schizophr Bull. (2017) 43:6937. doi: $10.1093 / \mathrm{schbul} / \mathrm{sbx} 057$

351. Jansen M, Overgaauw S, De Bruijn ERA. Social cognition and obsessive-compulsive disorder: a review of subdomains of social functioning. Front Psychiatry. (2020) 11:118. doi: 10.3389/fpsyt.2020. 00118

352. Wolmarans W, Stein DJ, Harvey BH. Social behavior in deer mice as a novel interactive paradigm of relevance for obsessive-compulsive disorder (OCD). Soc Neurosci. (2017) 12:135-49. doi: 10.1080/17470919.2016. 1145594

353. Andersen SL, Dumont NL, Teicher MH. Differences in behavior and monoamine laterality following neonatal clomipramine treatment. Dev Psychobiol. (2002) 41:50-7. doi: 10.1002/dev.10055

354. Smith JD, Rho JM, Masino SA, Mychasiuk R. Inchworming: a novel motor stereotypy in the BTBR T+ Itpr3tf/J mouse model of autism. J Vis Exp. (2014) 5:50791. doi: 10.3791/50791

355. Koteja P, Carter PA, Swallow JG, Garland TJr. Food wasting by house mice: variation among individuals, families, and genetic lines. Physiol Behav. (2003) 80:375-83. doi: 10.1016/j.physbeh.2003.09.001

356. Cameron KM, Speakman JR. The extent and function of 'food grinding' in the laboratory mouse (Mus musculus). Lab Anim. (2010) 44:298304. doi: 10.1258/la.2010.010002

357. Winter C, Greene DM, Mavrogiorgou P, Schaper H, Sohr R, Bult-Ito A, et al. Altered serotonergic and GABAergic neurotransmission in a mice model of obsessive-compulsive disorder. Behav Brain Res. (2018) 337:2405. doi: 10.1016/j.bbr.2017.09.015

Author Disclaimer: The work is solely the responsibility of the authors and does not necessarily represent the official view of the National Institutes of Health.

Conflict of Interest: AB-I is the President and CEO of OCRD Biomed LLC, which is pursuing patents for the use desformylflustrabromine as a novel treatment for obsessive-compulsive and related disorders.

The remaining author declares that the research was conducted in the absence of any commercial or financial relationships that could be construed as a potential conflict of interest.

Publisher's Note: All claims expressed in this article are solely those of the authors and do not necessarily represent those of their affiliated organizations, or those of the publisher, the editors and the reviewers. Any product that may be evaluated in this article, or claim that may be made by its manufacturer, is not guaranteed or endorsed by the publisher.

Copyright $\odot 2021$ Mitra and Bult-Ito. This is an open-access article distributed under the terms of the Creative Commons Attribution License (CC BY). The use, distribution or reproduction in other forums is permitted, provided the original author(s) and the copyright owner(s) are credited and that the original publication in this journal is cited, in accordance with accepted academic practice. No use, distribution or reproduction is permitted which does not comply with these terms. 